\title{
Archaeological and Historical Investigations at the West End of the Martin and Bowie Streets Connections, San Antonio, Bexar County, Texas
}

Bruce A. Nightengale

Anne A. Fox

I. Waynne Cox

Follow this and additional works at: https://scholarworks.sfasu.edu/ita

Part of the American Material Culture Commons, Archaeological Anthropology Commons, Environmental Studies Commons, Other American Studies Commons, Other Arts and Humanities Commons, Other History of Art, Architecture, and Archaeology Commons, and the United States History Commons

Tell us how this article helped you.

This Article is brought to you for free and open access by the Center for Regional Heritage Research at SFA ScholarWorks. It has been accepted for inclusion in Index of Texas Archaeology: Open Access Gray Literature from the Lone Star State by an authorized editor of SFA ScholarWorks. For more information, please contact cdsscholarworks@sfasu.edu. 
Archaeological and Historical Investigations at the West End of the Martin and Bowie Streets Connections, San Antonio, Bexar County, Texas

\section{Creative Commons License}

\section{(c) (1) \&}

This work is licensed under a Creative Commons Attribution-NonCommercial 4.0 International License 


\section{ARCHAEOLOGICAL AND HISTORICAL INVESTIGATIONS AT THE WEST END OF \\ THE MARTIN AND BOWIE STREETS CONNECTIONS, SAN ANTONIO, BEXAR COUNTY, TEXAS}

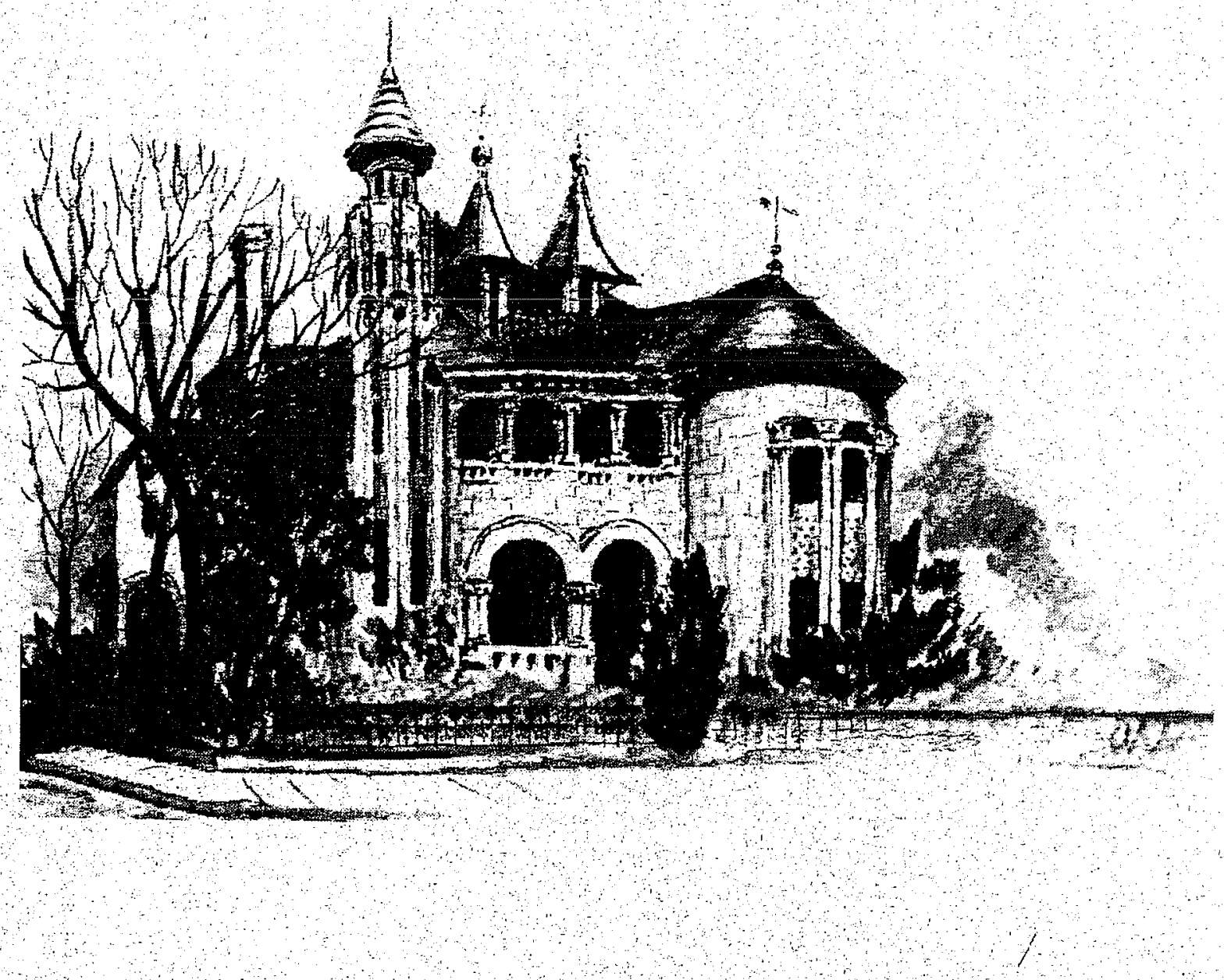

Bruce A. Nightengale, Anne A. Fox, and I. Waynne Cox

Center for Archaeological Research

The University of Texas at San Antonio

Archaeological Survey Report, No. 186 





\section{ARCHAEOLOGICAL AND HISTORICAL INVESTIGATIONS \\ AT THE WEST END OF \\ THE MARTIN AND BOWIE STREETS CONNECTION, \\ SAN ANTONIO, BEXAR COUNTY, TEXAS}

Bruce A. Nightengale, Anne A. Fox, and I. Waynne Cox

Texas Antiquities Committee Permit No. 759

Sponsor: City of San Antonio

Center for Archaeological Research

The University of Texas at San Antonio ${ }^{\circledR}$

Archaeological Survey Report, No. 186 
The following information is provided in accordance with the General Rules of Practice and Procedure, Chapter 41.11 (Investigative Reports), Texas Antiquities Committee:

1. Type of investigation: archaeological and historical;

2. Project name: Martin/Bowie Street West;

3. County: Bexar;

4. Principal investigator: Jack D. Eaton, coprincipal investigator and project director: Anne A. Fox;

5. Name and location of sponsoring agency: City of San Antonio through Day \& Zimmermann, Inc., San Antonio, Texas;

6. Texas Antiquities Committee Permit No. 759;

7. Published by the Center for Archaeological Research, The University of Texas at San Antonio, San Antonio, Texas 78285-0658, 1989.

A list of publications by the Center for Archaeological Research can be obtained by sending $\$ 1.00$ to the Center for Archaeological Research, The University of Texas at San Antonio, San Antonio, Texas 78285-0658. 


\begin{abstract}
Test excavations were conducted in November 1987 by the Center for Archaeological Research, The University of Texas at San Antonio at the site of a planned relocation of the eastbound lanes of Martin Street in downtown San Antonio. The lots in question were located on the north side of the early town site, and were known to have contained the residence of Thaddeus Smith, the county clerk for Bexar County in the last half of the 19th century. Testing was done by backhoe and by controlled hand excavations.

Testing was done in relation to each of the three structures that were known to have existed in the area. The foundations of a house at 409 North Flores Street, built in 1868, were examined to record methods of construction, the structural evolution of the house, and its conversion into a commercial establishment ca. 1927. Part of the foundations were uncovered and recorded of Smith's elaborate 1898 home at 403 North Flores Street. In search for the source of the late 18th-century artifacts from the levels beneath an 1868 house, test units were excavated at 401 North Flores Street in what appeared to be on the 1873 Koch map the back yard of a one-story adobe house. Artifacts recovered there, however, indicated post-1800 occupation. A jacal wall trench was located and recorded at this address.

As a result of the comparatively undisturbed nature of the archaeological deposits at 401 North Flores Street, it is recommended that the area bounded by Flores, Salinas, and Rossy Streets and the new location of Martin Street be made a State Archeological Landmark. A number of structures were located in this area in 1873 that undoubtedly represent the first expansion of the town to the north of the plazas.
\end{abstract}




\section{TABLE OF CONTENTS}

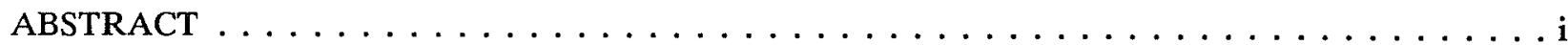

LIST OF FIGURES $\ldots \ldots \ldots \ldots \ldots \ldots \ldots \ldots \ldots \ldots \ldots \ldots \ldots$ ii

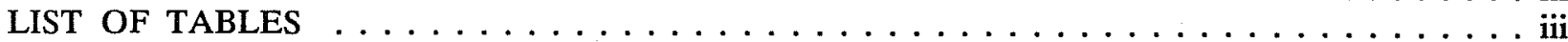

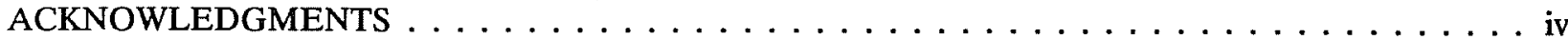

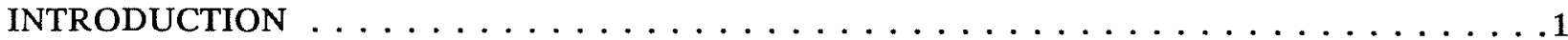

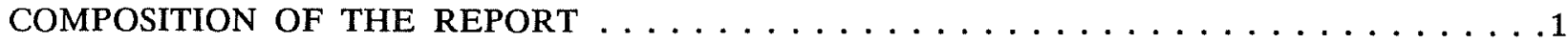

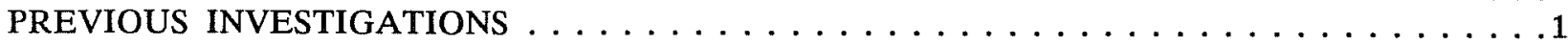

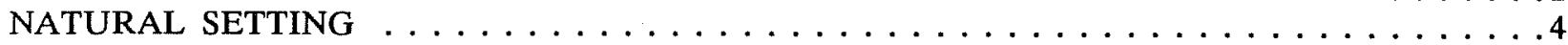

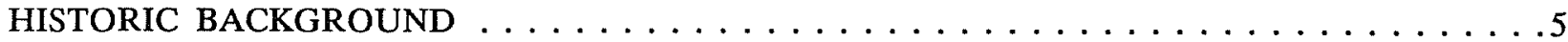

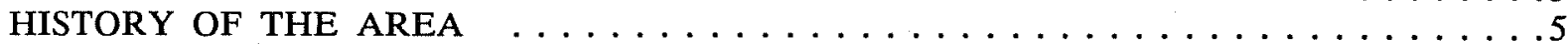

Lot A24, NCB 132 (The Smith Homestead) $\ldots \ldots \ldots \ldots \ldots \ldots \ldots \ldots$

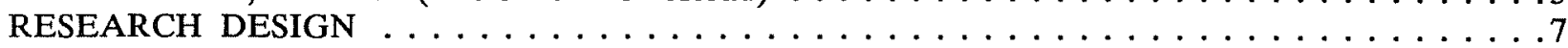

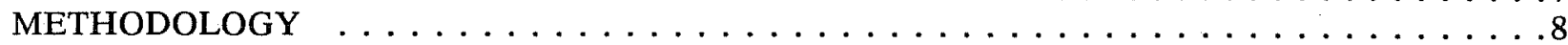

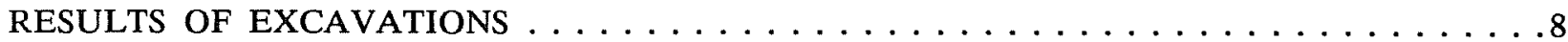

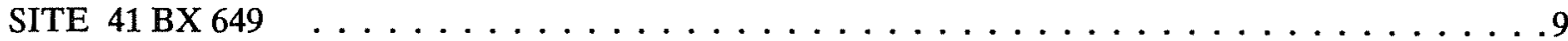

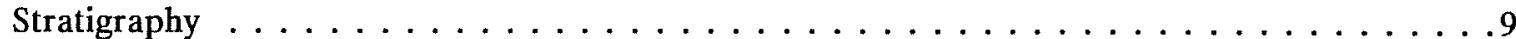

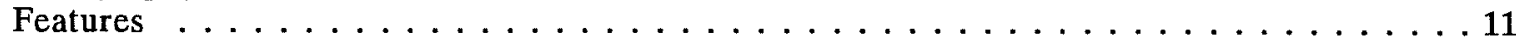

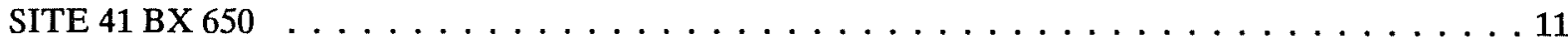

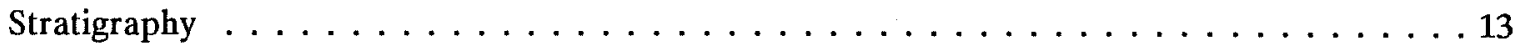

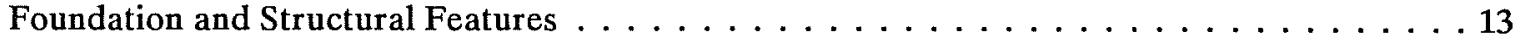

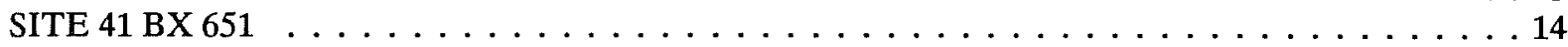

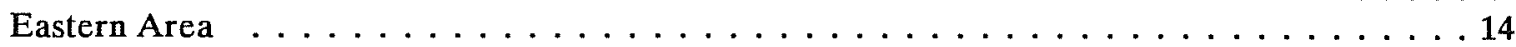

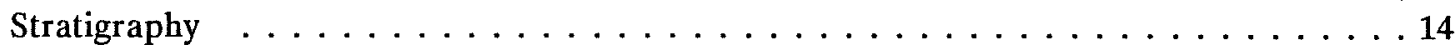

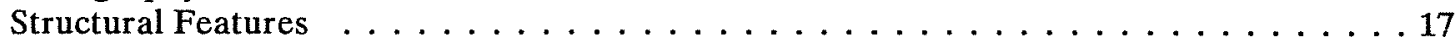

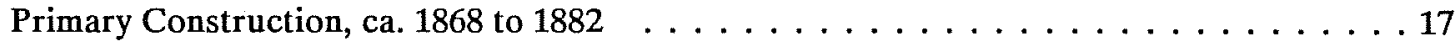

Secondary Construction and Modifications, ca. 1882 to $1958 \ldots \ldots \ldots \ldots$

Western Area . . . . . . . . . . . . . . . . . . . . . . . . . . . . . 19

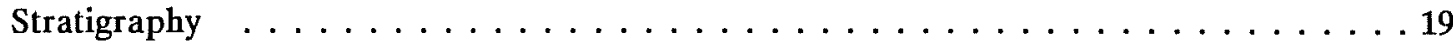

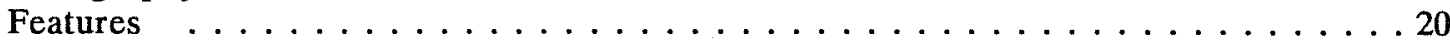

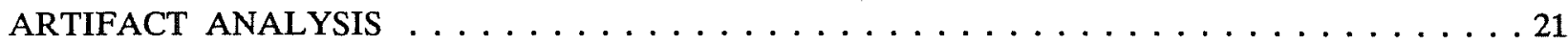

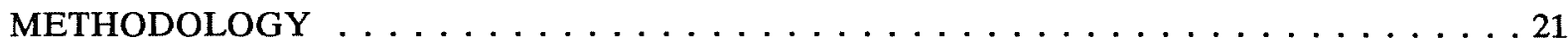

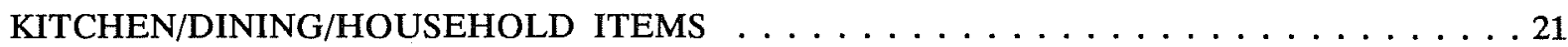

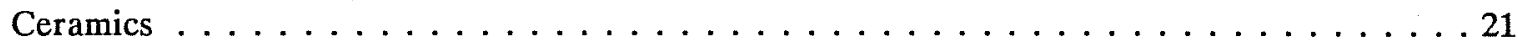

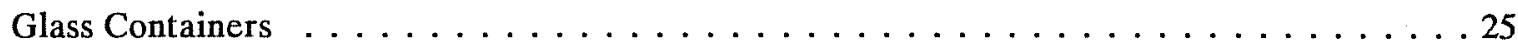

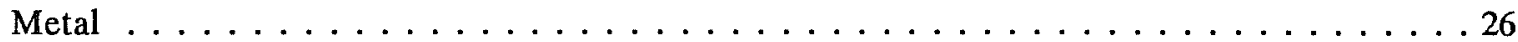

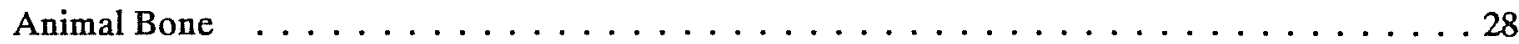

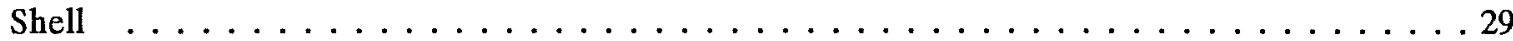

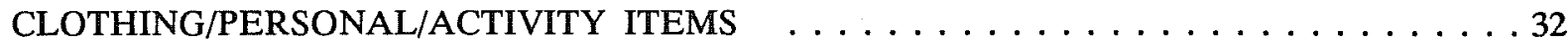

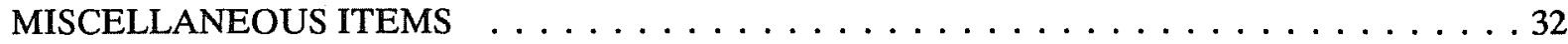

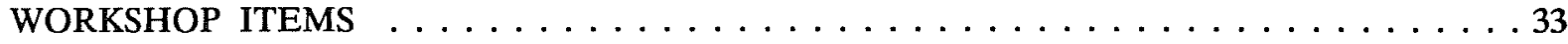

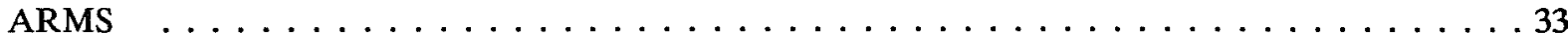

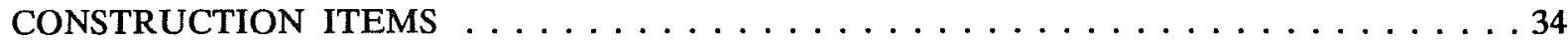

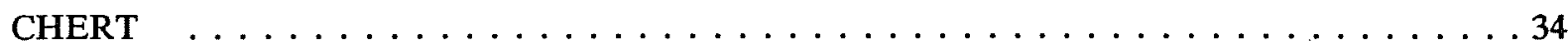

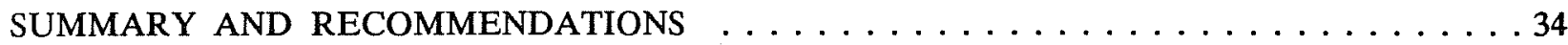

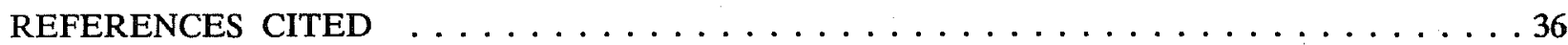




\section{LIST OF FIGURES}

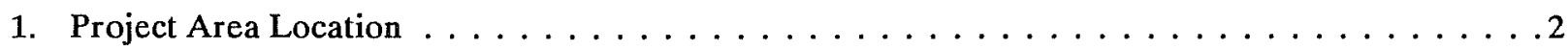

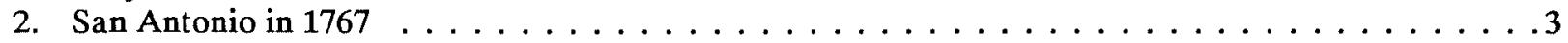

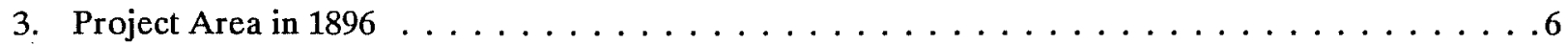

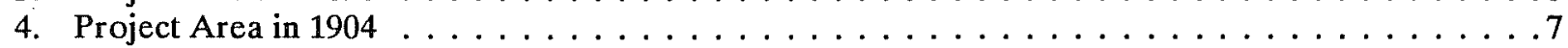

5. Location of Sites $41 \mathrm{BX} 649,41 \mathrm{BX} 650,41$ BX 651 , and Areas of Excavations . . . . . . 10

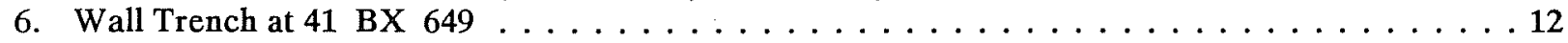

7. Sketch of Thaddeus Smith Home $(41$ BX 650$)$ in $1940 \ldots \ldots \ldots \ldots \ldots$

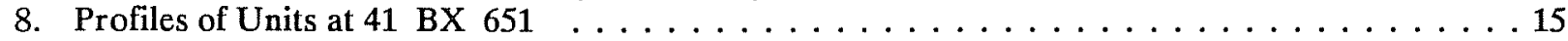

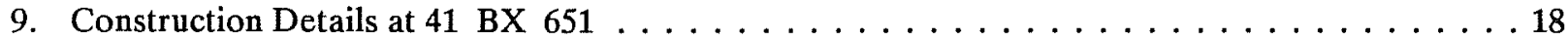

10. Unglazed, Lead-Glazed, and Tin-Glazed Wares $\ldots \ldots \ldots \ldots \ldots \ldots \ldots \ldots$

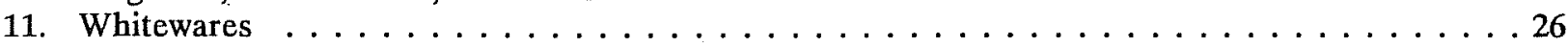

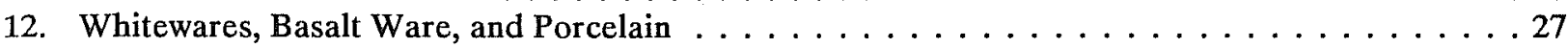

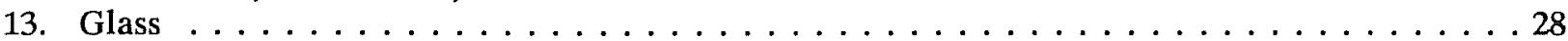

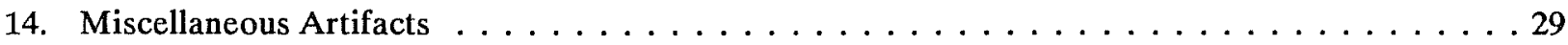

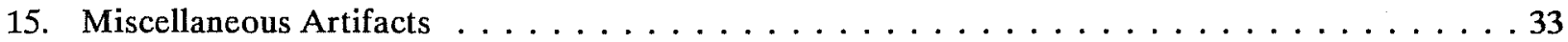

\section{LIST OF TABLES}

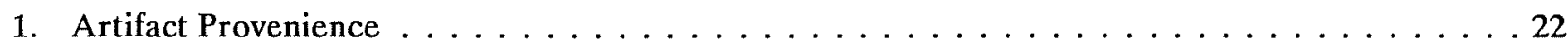

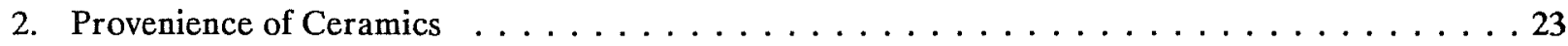

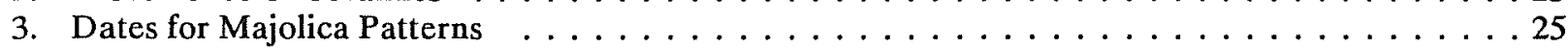

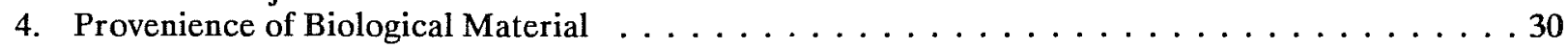




\section{ACKNOWLEDGMENTS}

We wish to acknowledge the help of a number of individuals without whom this project could not have been brought to a successful conclusion. Mike Carter of Day \& Zimmermann, Inc., coordinated our work with that of the overall project. We appreciate his patience with the vagaries of research archaeologists. As always, John Leal, county archivist was helpful in tracking down historical information.

A large vote of thanks to the following volunteer avocational archaeologists and anthropology students who contributed numerous hours in the field and enlivened our work with their enthusiasm:

\section{Christine Alcala \\ Darla Cox \\ Deborah Ellis \\ Scott Highley \\ Don McEwan \\ Frances Meskill}

\author{
Warren Miller \\ Shirley Mock \\ Russ Park \\ Burnley (Duke) Smith \\ David Turner \\ Gregg Wood
}

CAR staff members who served on the crew were Kenneth Brown, I. Waynne Cox, David Hafernik, Lynn Highley, and Rochelle Leneave. 


\section{INTRODUCTION}

In November 1987, archaeologists from the Center for Archaeological Research (CAR), The University of Texas at San Antonio (UTSA), conducted testing within the proposed roadway for the relocation of the eastbound lanes of Martin Street in downtown San Antonio (Fig. 1). The project was done for the City of San Antonio through the supervision of Day \& Zimmermann, Inc., under Texas Antiquities Committee Permit No. 759.

Martin Street runs east-west three blocks north of Main and Military Plazas, which are at the heart of the original 18th-century town site of San Antonio de Bejar. The project area consists of a portion of Lot A24 within New City Block (NCB) 132, bounded on the east by North Flores Street, on the south by Salinas Street, and on the west by Rossy Street.

The excavations were part of an archival and archaeological investigation by the CAR in advance of the rerouting of the roadway (Cox 1989). The area chosen for investigation is the only part of the western section of the proposed road that is not either a dedicated street or an area beneath which the archaeological deposits have been removed by basements of buildings or by demolition of structures.

The principal investigator for the project was Jack D. Eaton, acting director of the CAR. Coprincipal investigator and project director was Anne A. Fox of the CAR staff. Field director was Bruce A. Nightengale. A total of nine field days was expended by a field crew composed of UTSA anthropology students and local volunteers, which varied from day to day from four to seven members.

\section{COMPOSITION OF THE REPORT}

This report has been written as a cooperative effort by members of the research team who conducted the project. Bruce Nightengale wrote the sections on the setting, soils, methodology, and the description of the field work. I. Waynne Cox, the project historian, contributed the historical background. Anne Fox contributed the introductory statements, the information about previous work in downtown San Antonio, and the artifact descriptions and analysis. The final summary, conclusions, and recommendations were written by Nightengale in consultation with the other authors. The site map and location maps were drafted by Kenneth M. Brown, who also was in charge of mapping the site. David Hafernik drafted the other illustrations, in close cooperation with Nightengale and Fox. Frances Meskill also was instrumental in finalizing the illustrations.

\section{PREVIOUS INVESTIGATIONS}

The site of the original settlement of San Antonio included Main and Military Plazas and the areas directly to the north and east (Fig. 2). A number of archaeological investigations have been done in and around this area, the results of which have been helpful in understanding what was found during these excavations.

In 1975, the Texas Historical Commission conducted test excavations beneath the floor of San Fernando Cathedral on Main Plaza (Fox, Scurlock, and Clark 1977). Information on architectural details of the original parish church and cultural materials representing the earliest settlement of San Antonio (1720 to 1738) was recovered.

In 1976, the CAR conducted test excavations at the site of the Spanish Governor's Palace on Military Plaza (Fox 1977). Here, again, architectural and cultural information on the early settlement was recovered.

The CAR has carried out a series of excavations in conjunction with the new Bexar County Justice Center located across the street from the Bexar County Courthouse on Main Plaza (Fox 1978; Ellis 1986; Fox et. al. 1989). Artifactual information and details on early San Antonio construction techniques have been acquired from these excavations that contributed to this project. 


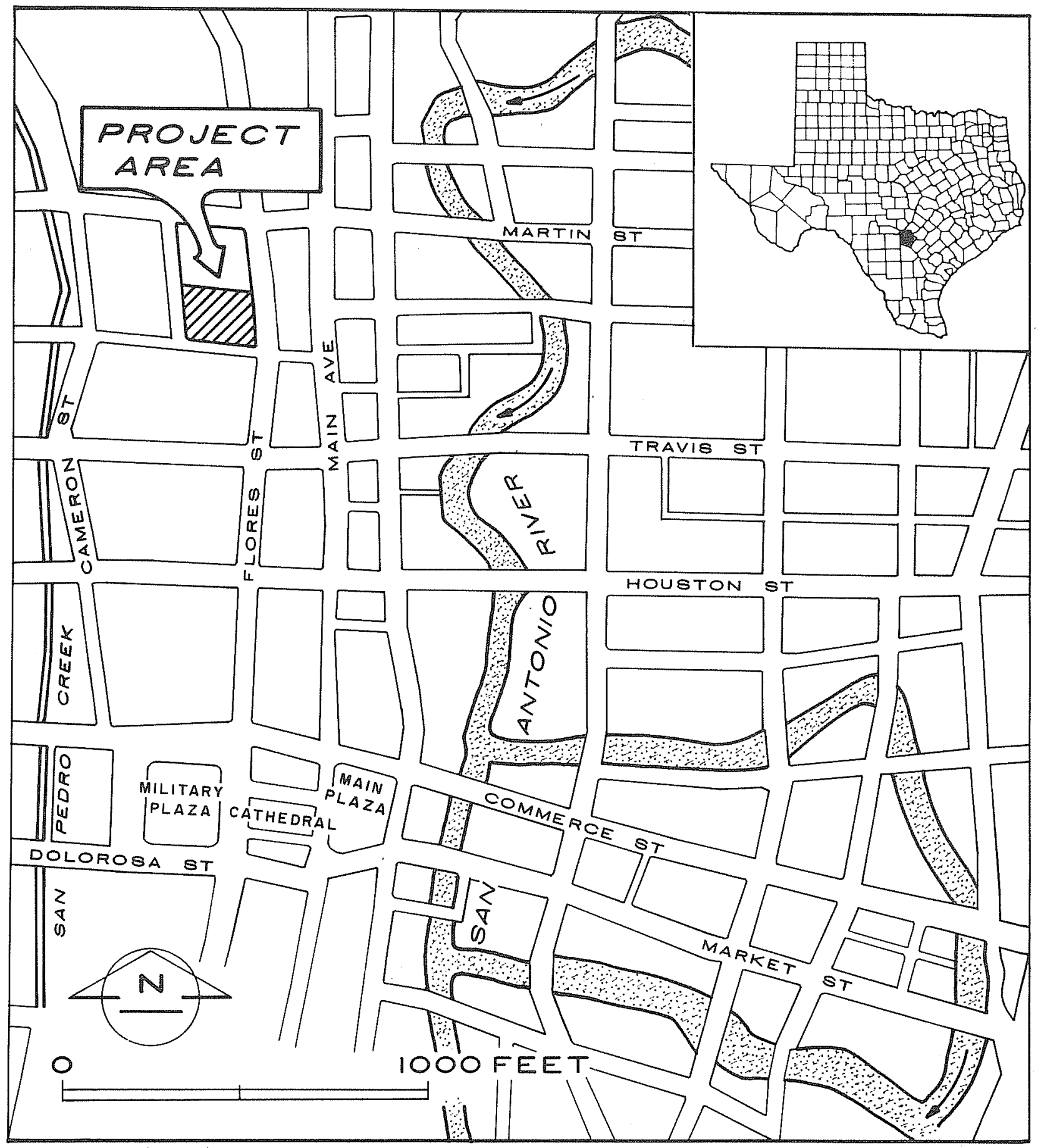

Figure 1. Project Area Location. 


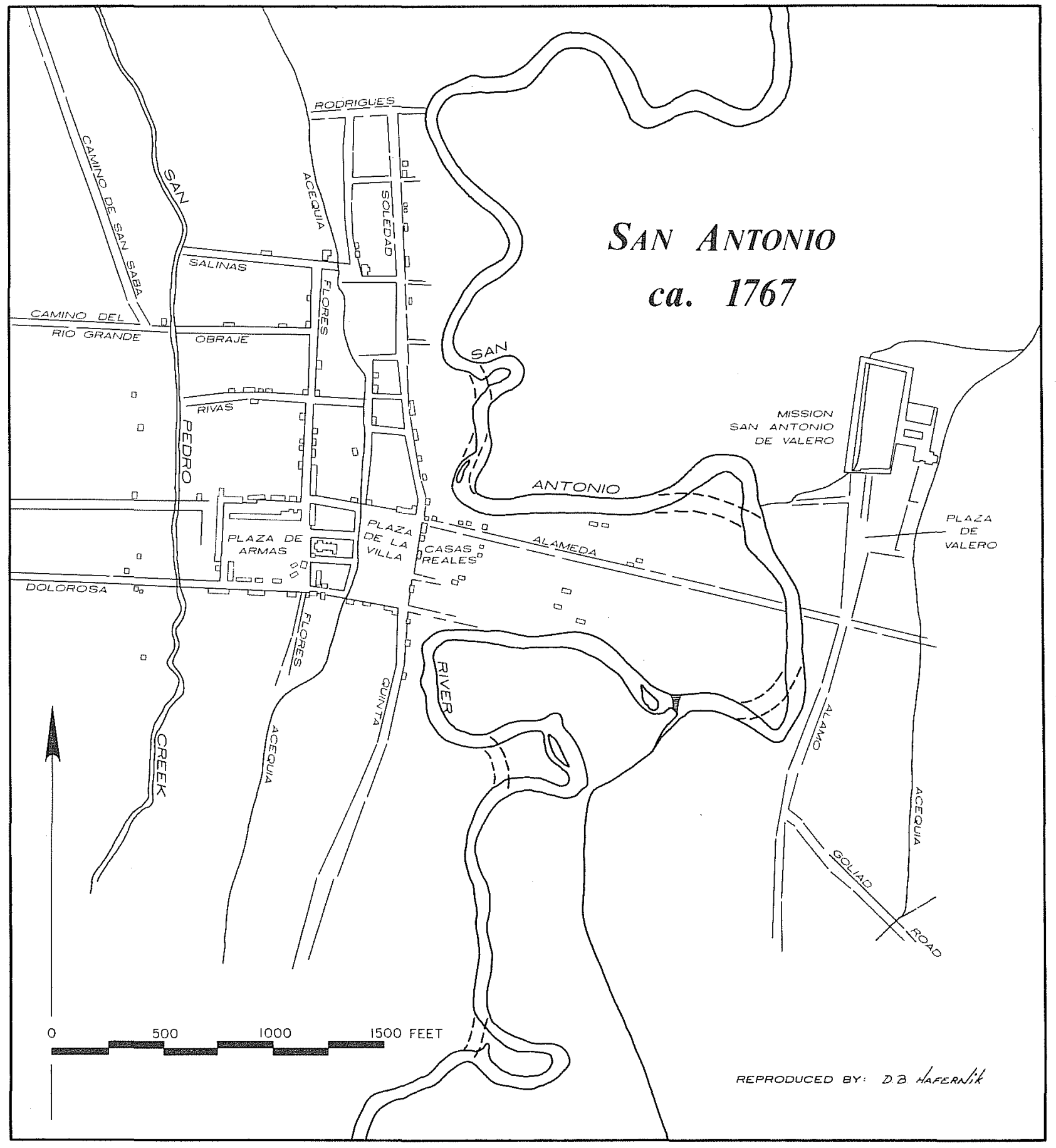

Figure 2. San Antonio in 1767. Map compiled by James Ivey from maps by Urrutia (1767) and Freisleben (n.d.). 
The CAR excavations in the area of La Villita, a small village that developed in the early 19th century across the river from the first settlement, have also provided background information. An emergency excavation there (Labadie, assembler 1986) in a Mexican siege works from the Battle of the Alamo, soon after filled with residential trash, has provided vital information on dating early 19th-century ceramics for this project.

James Ivey (1982) directed archaeological investigations at the site of the Menger Soap Works (41 BX 484) in 1979 for the present owner, Stanley Hammer and Company. The soap plant moved in 1861 from a location south of Houston Street to a lot facing north onto Martin Street, across San Pedro Creek from NCB 132. It was probably the first such commercial operation in this general area, which was at that time a residential district of the town. The waters of the creek were necessary to the operation of the plant.

In 1982, Anne Fox investigated the construction of a small "adobe" house across Salinas Street from NCB 132 (Fox 1982). A test pit excavated against the east wall of this house revealed details of footing, foundation, and wall construction strikingly similar to those at 409 North Flores Street. The estimated date of construction of this house, based on architectural and artifactual information, is 1856 (ibid.).

\section{NATURAL SETTING}

Lot A24 rests atop a portion of the black clayey alluvial plain that underlies most of downtown San Antonio. The clayey alluvium overlays older alluvial gravels and sediments that are underlain by Cretaceous formations of limestone and marl (Bureau of Economic Geology 1985). These natural strata border the southeast edge of the Balcones Escarpment, a fault zone along the edge of the Edwards Plateau (ibid.). Headwater tributaries flowing from the higher elevations of the plateau feed major local drainages cutting southeast across and into the plain. The lot is located on a low Holocene terrace of the San Antonio River. Elevation measures approximately 650 feet above mean sea level.

Pertinent to settlement in the area are the San Antonio River on the east of Lot A24 and San Pedro Creek on the west, the latter a main tributary of the former. As a result of downcutting and erosion, an interfluvial divide has formed between the neighboring valleys. Lot A24 is located on the western crest and slope of the divide, overlooking San Pedro Creek. An approximate 1.6\% slope spans the 500-foot distance between the edge of the divide and the present location of the creek bank. At present, the slope is covered by asphalt parking lots bordered by paved streets. Between the asphalt surface and the naturally deposited alluvial clays at Lot A24 are several layers of artificial fill brought in to level the area. Of importance to understanding some aspects of early historic land use relating to Lot A24 is the interrelationship of hydrology and topography.

The divide provided an avenue of gradual descent from north to south for the San Pedro acequia, which is located approximately 100 feet east of Lot A24. The acequia, constructed in the early $1700 \mathrm{~s}$, provided water from San Pedro Springs for irrigation of cultivable land between the springs and the Presidio de Bejar (Frkuska 1981:2). It also supplied water to the Presidio and town proper (ibid.). The highly fertile soils of the Houston Black Clays and Trinity and Frio soil series (Taylor, Hailey, and Richmond 1966) found beneath the layers of fill at the lot were probably tilled and plowed for cultivation when this area was at the northern edge of the town with only a couple of residences (Fig. 2). Later use of the land for residential and commercial purposes resulted in the covering of the natural soils with fill and artificial surfaces. After 1958, no standing structures remained. Lot A24 had become an asphalt parking lot. Sequences of land use associated with the lot are discussed in the "Historic Background" section of this report. The several strata of artificial fill between the present surface and the alluvial clays are described in the "Results of Excavation" section. 


\section{HISTORIC BACKGROUND}

\section{HISTORY OF THE AREA}

The area in which the project lies was irrigated farmland during the 18th century and is not known to have been developed until the mid-19th century. San Pedro acequia ran down the divide between the San Antonio River and San Pedro Creek about half a block east of NCB 132.

A map of the town ca. 1767 (Fig. 2) shows a dwelling on the north side of Salinas Street near what would later be the approximate southwest corner of Lot A24, and another on what would have been the northeast corner of North Flores and Salinas Streets. At that time, North Flores Street did not extend beyond Salinas Street. There were no houses north of these streets between the acequia and San Pedro Creek.

In 1873 (Koch 1873), the area had become residential and remained so until commercial activities began to encroach about 1910 to 1920 . By 1959, all the original residential structures had been replaced by large, oneand two-story commercial buildings. Lot A24 by this time had become a parking lot.

\section{Lot $\mathbf{A 2 4}, \mathrm{NCB} 132$ (The Smith Homestead)}

Lot A24 was originally a small portion of a property composed of two lots running north from Salinas Street and from Flores Street to San Pedro Creek. They were purchased by Francisco José Salinas from Mariano and Antonia Rodriguez and Priest José Antonio Valdez of Goliad. In 1831, Salinas' widow, Margila Chirina, sold the northern half of the property to José Antonio Navarro (DR Vol. C1:37). The Salinas homestead appears to have been located either between the acequia and San Pedro Creek fronting on Salinas Street, near present-day Rossy Street, or on the southeast corner of Flores Street beside the acequia (Fig. 2). The remaining portion of the property passed to her heirs upon her death in 1860 . The administrator of her estate was her granddaughter, Antonia Monjares y Mesa, wife of Francisco Mesa (Chabot 1937:154). A one-story "adobe" at the corner of Salinas and Flores Streets, as shown on the 1873 bird's eye view map of the city of San Antonio (Koch 1873) and the 1896 Sanborn insurance map (Fig. 3) may have been the Mesa homestead. In 1868, the Mesa heirs sold the upper portion of Lot A24 to Francis Rose, who probably constructed the house at 409 North Flores Street at that time ( $R R$ Vol. U1:363).

In 1877, Rose deeded this lot, and other property he owned to the north, to Guadalupe Rivas y Rose, his wife ( $D R$ Vol. 6:421). In 1881, she conveyed the property to Dr. Amos Graves and his wife, Georgia (DR Vol. 28:141). Dr. Graves occupied a home farther north on Flores Street, so the property was probably used for rental income.

In 1882, Dr. and Mrs. Graves conveyed the property and the structure to Thaddeus Wood Smith, the county clerk, by warranty deed ( $D R$ Vol. 29:1). By the following year, 409 North Flores Street had become the Smith residence (City Directory 1883-1884). Smith and his family resided in the house until about 1898, when he constructed a stone Victorian residence on the corner at 403 North Flores Street (Fig. 4; DR Vol. 49:510; City Directories 1896-1900). The construction of the new house probably coincided with the demolition of the other structures on the lot, including the small stone house at 401 North Flores Street. The new house was to remain Smith's residence until his death in 1933, at the age of 75 (USDI-OC 1880; Wills and Probate Records No. 21432). His widow moved elsewhere prior to 1936, and the property became a residential rental until 1957 when it was occupied by KEXX Radio, who remained there until the property was cleared in 1958 to become a parking lot (City Directories 1933-1958).

Apparently after the construction of the residence at 403 North Flores Street, Smith transferred the property at 409 North Flores Street to John $\mathbb{P}$. Geraghty, but the record of transfer could not be located in the county records (City Directories 1897-1909). It remained residential until about 1927, when it became commercial property. It is likely that an addition to the east was built at this time. The building was destroyed in 1958, at the same time as the property to the south (City Directories 1909-1958). 


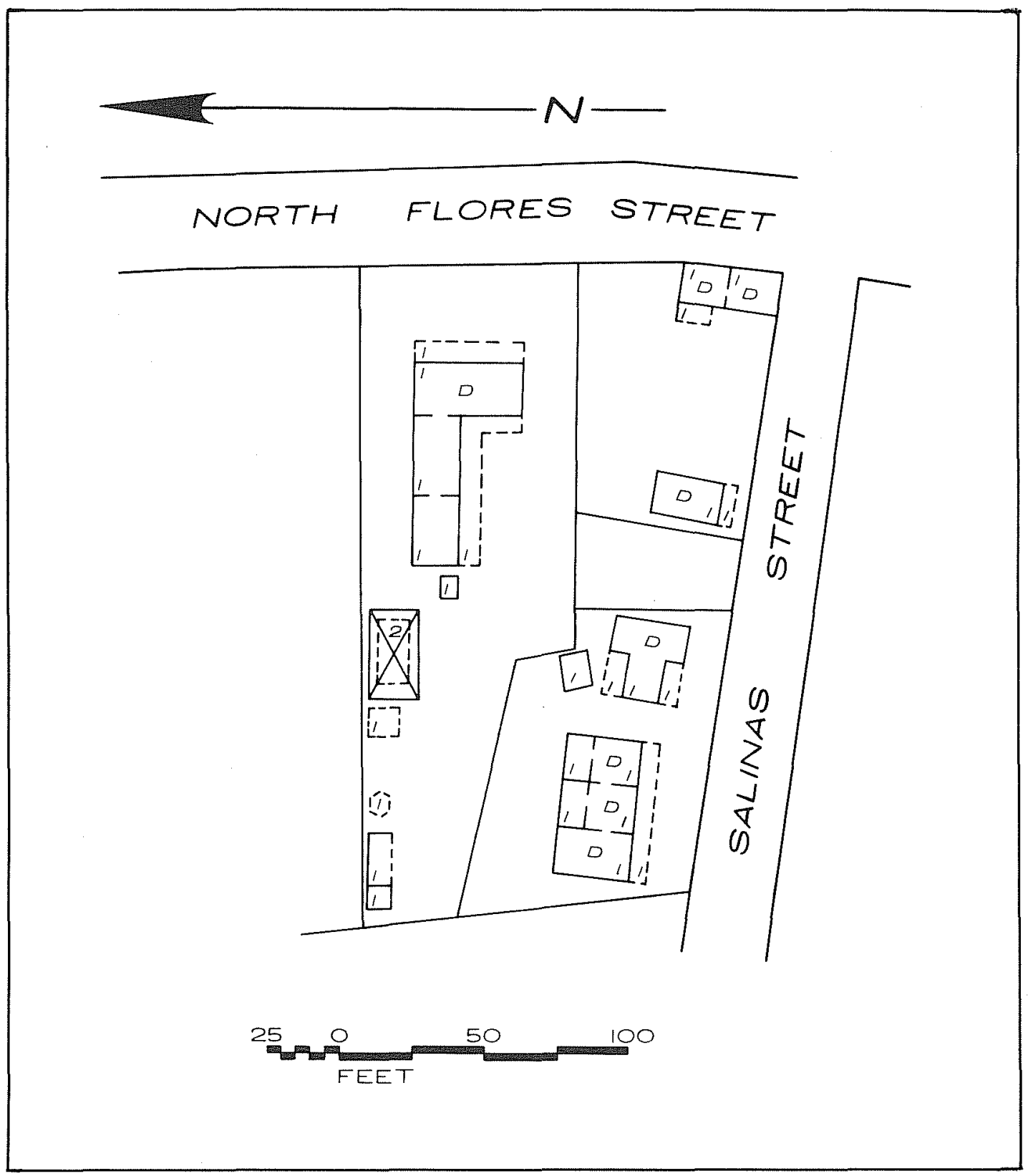

Figure 3. Project Area in 1896. Adapted from Sanborn Map and Publishing Company, Ltd. (1896) map. " $D$ " stands for dwelling; " 1 " indicates a one-story dwelling; " 2 " indicates a two-story dwelling. 


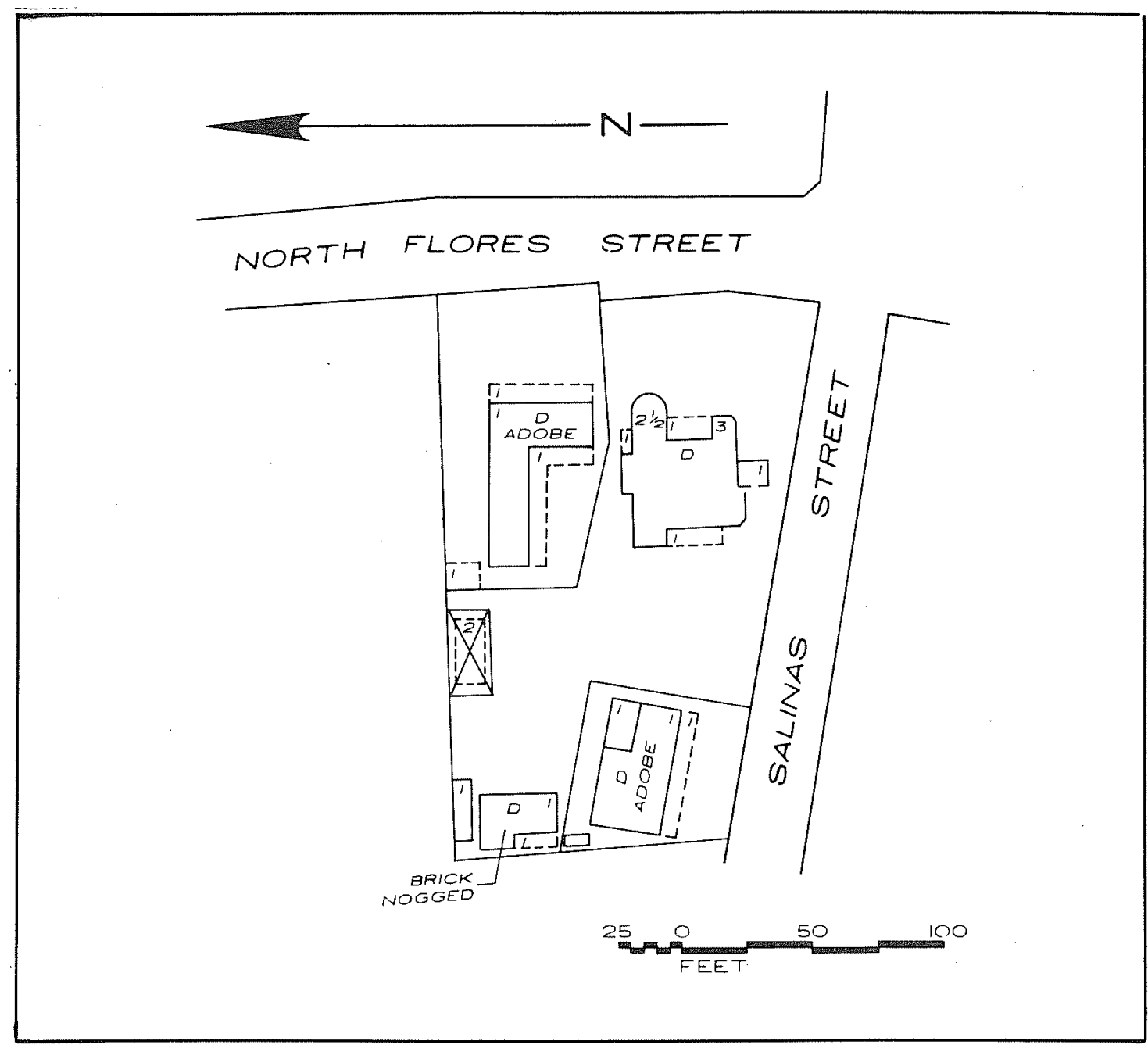

Figure 4. Project Area in 1904. Adapted from Sanborn Map and Publishing Company, Ltd. (1904) map. " $D$ " stands for dwelling; " 1 " indicates a one-story dwelling; " 2 " indicates a two-story dwelling.

Martin Street, originally Lakeview or Lake Street, was created in 1921 by an extension through the area from the San Antonio River toward the western suburbs ( $D R$ Vol. 638:479). Rossy Street was constructed between 1922 and 1926 (City Directories 1921-1928). In the early 1920s, Flores Street was widened to the west, bringing the front of 409 North Flores Street to the edge of the sidewalk and causing most of the house site at 401 North Flores Street to be buried under the street and sidewalk.

\section{RESEARCH DESIGN}

The purpose of these excavations was as follows:

1. To recover whatever information that could still be obtained from the lot prior to its obliteration by road construction.

2. To record the construction techniques from the 19 th century and early 20 th century in San Antonio. 
3. To look for evidence of the growth of the first settlement to the north from the plazas.

4. To observe artifactual and structural changes related to the evolution from residential to commercial use of the property.

\section{METHODOLOGY}

Subsurface investigations at Lot A24 required the combined use of a backhoe and hand-excavated units. Backhoe excavations in downtown San Antonio have proven to be a practical and efficient method for subsurface assessment of cultural resources (Katz 1978; Fox 1978; Ellis 1986). As a result, more area is exposed for assessment so that subsequent hand excavations and documentation can be based on a larger body of data. During the present project, the backhoe was used to remove the asphalt surface and underlying fill in search of house foundations; to follow out and expose house foundations at $41 \mathrm{BX} 650$ and $41 \mathrm{BX} 651$; to scrape off asphalt and fill to expose a surface for grid and subsequent hand excavations at $41 \mathrm{BX} 651$; and to dig a 60-foot long, 30-inch-deep east-west exploratory trench at $41 \mathrm{BX} 651 \mathrm{West}$. The profile from the south wall of the trench was used to guide further machine excavation of the overlying artificial strata. Thereafter, hand-excavated units measuring $5 \times 5$ feet were chosen from a group of gridded squares laid out at each of the scraped areas.

Since each area is part of a separate site, the southeast stake at each grid was designated N100 W100. Each individual 5- $\mathrm{x}$ 5-foot unit within the grid was identified by the coordinates of the southeast stake. Vertical datums were different from site to site. At $41 \mathrm{BX} 651 \mathrm{West}$, measurements were taken from the southeast stake of each unit, while those at the chimney base excavations on the eastern portion of the site were taken from the base of a metal post set into the asphalt surface to support a money collection box used by patrons of the parking lot. At $41 \mathrm{BX} 649$, measurements for all excavated units were taken from the N110 W105 stake. Except for $41 \mathrm{BX} 651$ East, units were excavated in natural or arbitrary 6-inch levels. The area of excavation at $41 \mathrm{BX} 651$ East focused on subfloor clayey deposits on the north and east side of a chimney base. The area was excavated until cultural deposits became minimal to nonexistent.

Horizontal boundaries for the investigation were set by measuring the width of the proposed street across the lot surface and marking the outline with spray paint. The width was based on plan maps provided by the

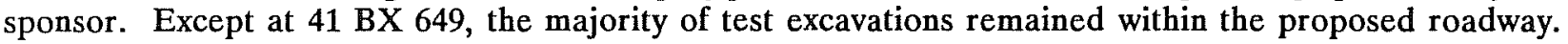
Excavations were undertaken at $41 \mathrm{BX} 649$ because that portion of the lot purportedly contained an earlier structure than those found at 41 BX 650 and 41 BX 651, and therefore may have been the source of late 18thand early 19th-centuries artifacts found in the upper 10 to 15 inches of dark brown clayey soils beneath the structure at $41 \mathrm{BX} 651$ East and test units at $41 \mathrm{BX} 651$ West.

Location of possible structures was based on extensive historic background research and early maps of the area. These included 1896 and 1904 Sanborn insurance maps (Sanborn Map and Publishing Company, Ltd. $1896,1904)$ and an 1873 bird's eye view map of the city (Koch 1873).

All measurements are English system units, i.e., feet and inches. Documentary photographs include $35 \mathrm{~mm}$ black and white and color, as well as Polaroids of pertinent features and general views. Wall profiles, sketch maps of unit floors, features, and structural remains were drawn where warranted. The overall layout of excavations at the three sites and the boundaries of the lot were mapped from a single datum with plane table and alidade. Level notes were kept for each unit level excavated. Daily journal notes were kept for the entire field project. Each site was assigned a trinomial number and recorded on both State of Texas and CAR site forms. All notes, photographs, maps, sketches, and collected artifacts are on file and curated at the laboratory of the CAR-UTSA.

\section{RESULTS OF EXCAVATIONS}

As a result of subsurface investigations at Lot A24, three separate sites were recorded. Sites $41 \mathrm{BX} 649$, $41 \mathrm{BX} 650$, and $41 \mathrm{BX} 651$ contain remnants of three separate structures from possible 18th century as well 
as 19 th century and 20th century occupations on North Flores and Salinas Streets. Descriptions and results of excavations at each site follow.

\section{SITE $41 \mathbb{B X} 649$}

Site 41 BX 649 is located on the northwest corner of North Flores and Salinas Streets (Fig. 5). Based on preliminary research of Lot A24, the corner as well as the area to the west facing Salinas Street contained structures dating from the late 1700 s and early 1800 s. Though out of the proposed roadway, the area was tested to ascertain the origin of early artifacts found at $41 \mathrm{BX} 651$. As North Flores Street has been widened to the west since the early maps were drawn, only the back yard area was thought to remain in the area of excavation. Finding a large quantity of artifacts from the same time period as those found farther north beneath $41 \mathrm{BX} 651$ would suggest that those deposits were related to this site.

After removing approximately 12 inches of sterile fill and asphalt from a $20-\times 20$-foot area with the backhoe, a 10- x 15-foot grid of 5- x 5-foot squares was placed over the exposed surface. As a result, all measurements labeled below datum are actually +12 inches below the asphalt surface. Two 5- x 5-foot units (N105 W105 and N110 W100) and a 2.5- $x$ 5-foot unit (N105 W100) were excavated in natural, then in arbitrary 6-inch levels. Artificial fill strata were considered as natural levels. When in situ strata were encountered, arbitrary 6 -inch levels were employed for refined recovery within the natural stratum. Excavations at the site exposed one artificial fill stratum and two strata in situ. Three levels were excavated to a maximum depth of 17 inches below datum, where artifact content diminished.

\section{Stratigraphy}

Stratum 1 was an artificial fill that measured to 6 inches below datum. The upper 2 to 2.5 inches was a remnant of the "caliche" fill (10YR 8/2) layer stripped off by the backhoe. In Unit N110 W100, only 2 to 2.5 inches of caliche were present. In Units N105 W105 and N105 W100, Stratum 1 continued another 4 inches to include a linear arrangement of limestone rock fragments not seen in the former unit. They were present in the north half of both units, oriented east-west at approximately 2 to 6 inches below datum. Underlying the rock alignment was a caliche-filled wall trench (Feature 1). To the south, the remainder of Unit N105 W105 was covered with smaller limestone fragments mixed in a sandy clay matrix at approximately the same depth. The limestone and clay layer in the south part of the unit overlay a 20 - $x$ 40-inch concentration of artifacts, bone, and charcoal (Feature 2). At 6 inches below datum, excavations ceased in Unit N105 W100. The unit was initially opened to follow out the wall trench found in Unit N105 W105. With the exposure of the trench surface, the objective was accomplished, and no further excavation was done. Stratum 1 comprised Level 1 in all units. Artifacts found within Level 1 varied in quantity and type from unit to unit, but a mid- to late-1800s date is suggested for this stratum.

Stratum 2 was a light brownish gray clayey matrix (10YR 6/2) with numerous charcoal flecks dispersed throughout. Average thickness was 10 inches. In Unit N105 W105, Stratum 2 comprised Level 2 (6-12 inches below datum) and Level 3 (12-17 inches below datum). In the north portion of the unit, a 5-foot length of wall trench was present. In the south portion, the Feature 2 area constricted to approximately an $8-x 10$-inch area along the south wall. Adjoining the west side of Feature 2 lay Feature 3, a compacted clayey surface at approximately 8-10 inches below datum. In Unit N110 W100, the stratum comprised Level 2 (3-11 inches below datum). Though some mixing is apparent, artifacts from Level 2 indicated a mid-1800s accumulation. In Unit N105 W105, artifacts from Level 2 indicated an early to mid-1800s date, while those in the underlying Level 3 were predominantly from the early 1800 s.

Stratum 3 was a dark grayish brown clayey soil (10YR 3/1). Only the upper 3 to 6 inches of the stratum was excavated in Unit N110 W100 where it comprised Level 3. Here the excavated portion of the stratum measured from 11 to 17 inches below datum at the deepest point. In Unit N105 W105, only a 2-inch segment was excavated on the north side of the wall trench. This was the only area where the stratum was present in the unit. The remaining area of the unit floor (17 inches below datum) south of the 10-inch-wide wall trench contained dispersed caliche mottles within a matrix analogous to Stratum 2. Excavations ceased in both units 


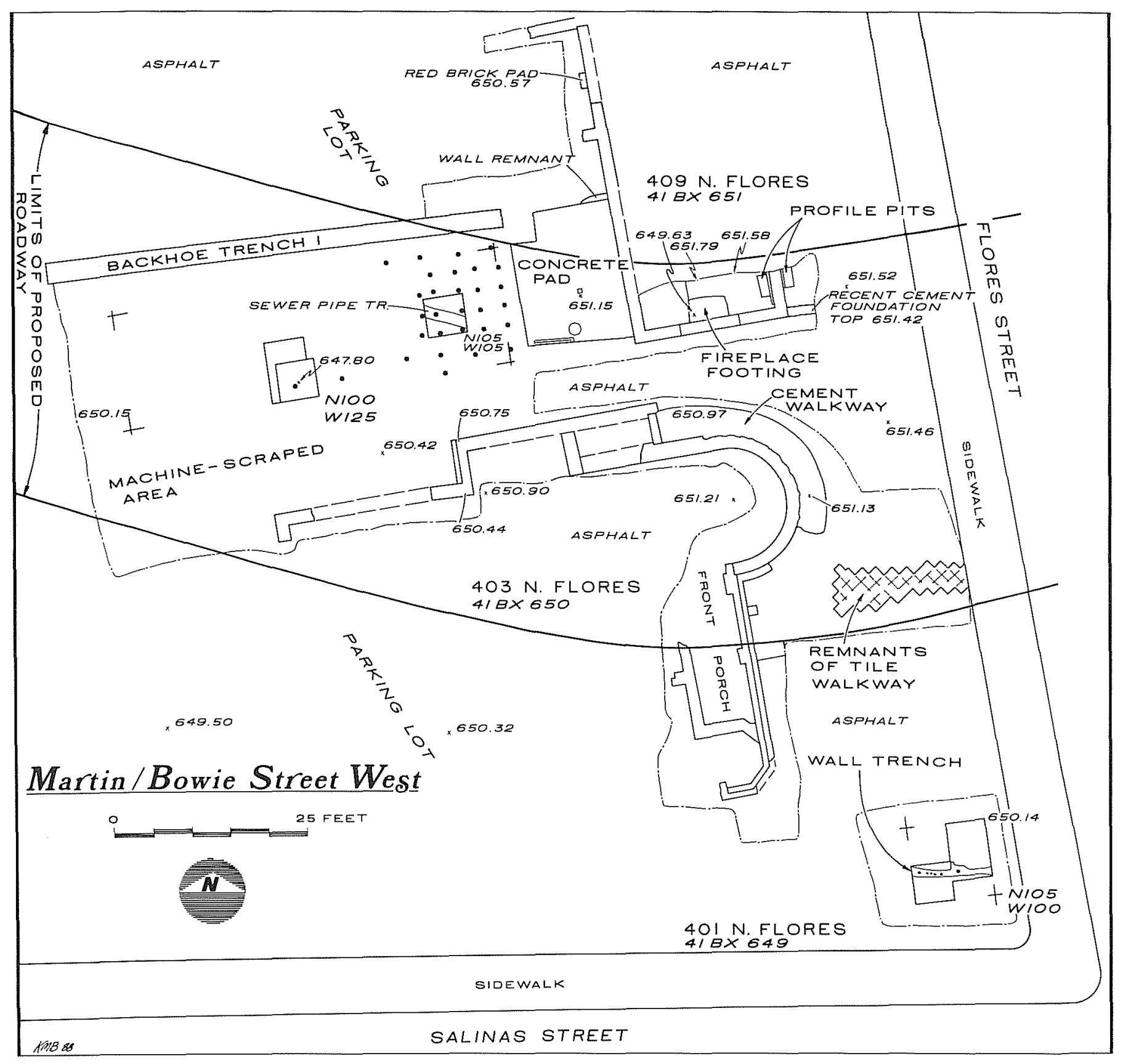

Figure 5. Location of Sites $41 B X 649,41 B X 650,41 B X 651$, and Areas of Excavation. 
at 17 inches below datum. Only a 36- $x$ 42-inch area in the northwest corner of Unit N110 W100 was excavated to this depth. This was done to test the vertical limits of cultural deposits within the matrix. The remainder of the unit had been excavated to the horizon boundary between Strata 2 and 3. The limited quantity of artifacts from Level 3 in Unit N110 W100 was predominantly pre-1850s.

\section{Features}

Feature 1 (Fig. 6) was a caliche-filled trench running east-west along the north side of Units N105 W105 and N105 W100. The trench measured 10 inches in width and 10 feet in exposed length. Excavations in Unit N105 W105 did not reach the bottom of the trench. When excavations ceased at 17 inches below datum, the trench was still visible in the floor of the unit, suggesting greater depth. Remnants of six vertical posts were exposed within the caliche fill in Unit N105 W105. Each measured about 3 inches in diameter. The distance between posts was irregular. In Unit N105 W100, a 7-inch diameter posthole was recorded in the surface of the trench at the west end nearest Unit N105 W105. As excavations in this unit went no deeper than the surface of the trench, it could be conjectured that more posts lay deeper within the caliche fill. Overlying the trench surface in both units was a linear accumulation of piled limestone fragments each measuring from 5 to 10 inches in length. At its widest, the accumulation measured 30 inches. One fragment of dressed stone and several brick fragments were observed in the accumulation. Outlines of the trench in the west wall of Unit N105 W105 and the east wall of Unit N105 W100 indicated a continuation of the wall trench in both directions.

Feature 2 was a concentration of cultural debris extending north from the south wall of Unit N105 W105. Artifacts, bone, and charcoal were concentrated in a 20- x 20-inch area of dark matrix. The feature was first observed at 6 inches below datum and continued to approximately 13.5 inches below datum where it contracted to an 8- $x$ 10-inch area of dark matrix. The concentration appeared to be a trash pit probably extending south into an unexcavated area.

Feature 3 (Fig. 6) was a hard-packed clay surface protruding from the south wall in the southwest corner of Unit N105 W105. The 10- $\mathrm{x} 20$-inch surface was exposed at 8 inches below datum nearest the south wall and sloped north to 10 inches below datum. The feature appeared to be a remnant of a living surface that had been packed and hardened from continuous use.

\section{SITE 41 BX 650}

Excavations at site $41 \mathrm{BX} 650$ entailed the use of a backhoe and noncontrolled hand excavations to expose the foundation of a house constructed in the late 19th century for Thaddeus Wood Smith (Fig. 5). The three-story house was located at 403 North Flores Street facing eastward toward the street. Preliminary investigation into the historic background of the lot indicated that the structure had been located in the southeast portion. In order to ascertain the exact location, a backhoe was used to remove the upper 6 inches of caliche fill and asphalt. After exposing the foundation, the backhoe was used to follow out portions of the foundation alignment along the east and north sides. Thereafter, hand excavations were used to uncover and clean off portions of the foundation and footing for measurement and identification. In all, a total of 56 feet of foundation was exposed along the north side and 48 feet along the east side. Both the southeast and northwest corners of the foundation were exposed during excavations at the site; hence about $50 \%$ of the foundation lay exposed to investigation and subsequent documentation. As part of the documentation, construction materials were identified as were the construction methods. The 1904 Sanborn insurance map (Fig. 4) and an artist's rendition of the structure (Fig. 7) were used as guidelines for excavation. 


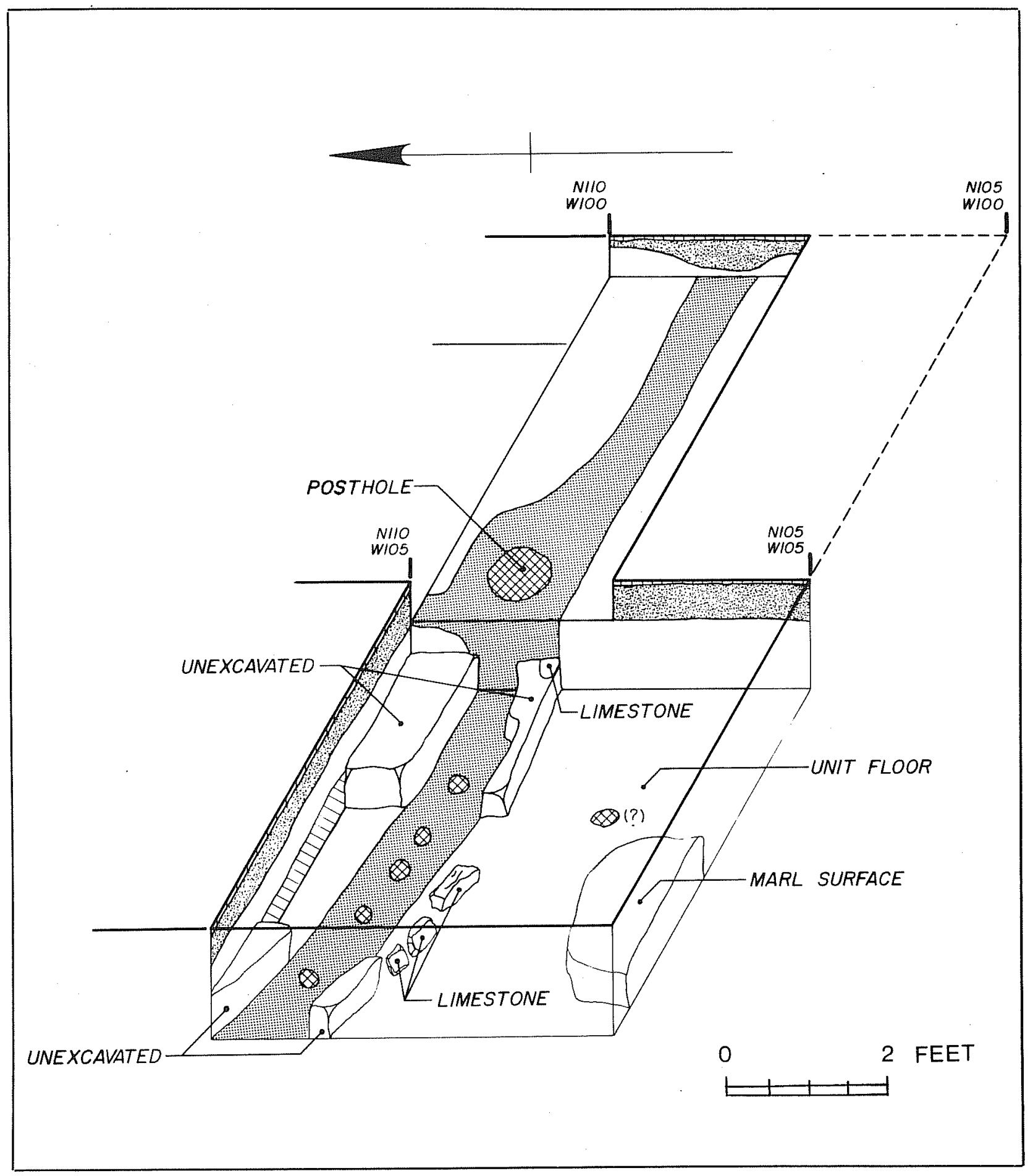

Figure 6. Wall Trench at $41 B X 649$. 


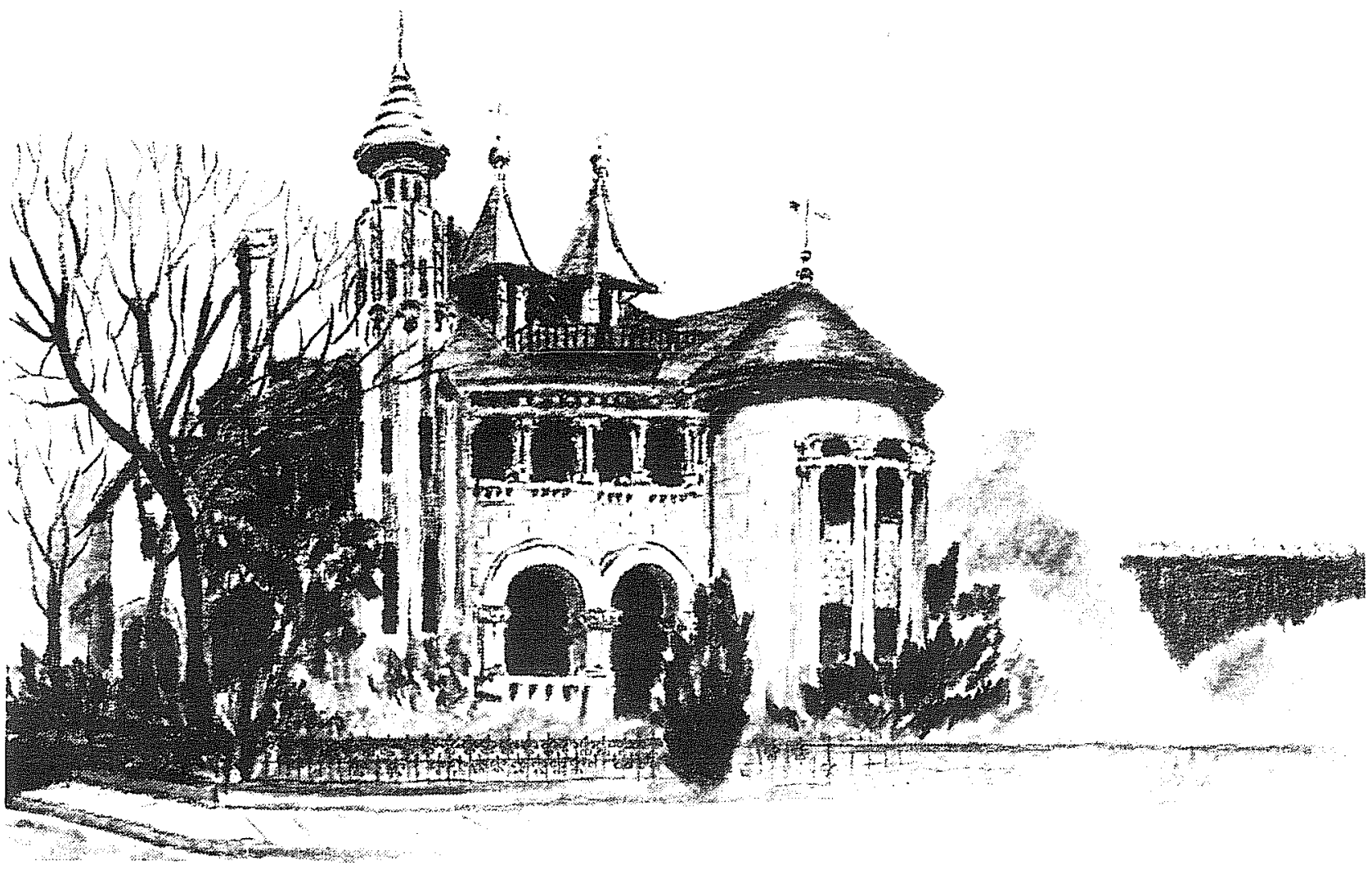

Figure 7. Sketch of Thaddeus Smith Home (41 BX 650) in 1940. Taken from Hagner (1940:38). The architect for the house was James Riely Gordon.

\section{Stratigraphy}

Stratum 1 was a 2-inch layer of asphalt paving material.

Stratum 2 was a 4-inch-thick yellowish gravelly fill used as a base for the asphalt paving.

Stratum 3 was a dark grayish brown clayey soil into which the footing trenches were dug.

\section{Foundation and Structural Features}

Foundation and footing material consisted of machine-made and handmade Laredo brick courses faced with limestone. The 3-foot-wide brick courses constituted an inner wall which was faced on the exterior with limestone and on the interior with plaster. Several exposed courses of brick remained after the 1958 razing of the structure.

Structural features included a porch and front step foundation on the east between a large tower foundation on the northeast and a smaller one in the southeast corner. Leading from North Flores Street to the front porch were remnants of a walkway constructed of concrete cubes with alternating brown and dark gray surfaces. Also uncovered was a 3-to-4-foot-wide semicircular concrete walkway that bordered the outside of the northeast tower, leading from the front steps to a side entrance. On the north side of the house, at the end of this walk, a block of red granite apparently served as the base of a stairway leading to the entrance door. 
Diagnostic artifacts were collected from the surface and areas around the foundations. Two marbles, one of glass and the other of clay, were collected from an area against the porch foundation. Though some ccramic fragments were collected, the majority of artifacts were glass fragments and glass bottles from the late 1800 s and early 1900s. On the whole, very little in the way of cultural debris was found around the house.

\section{SITE 41 BX 651}

Site 41 BX 651 is located at 409 North Flores Street in the northeast portion of the lot (Fig. 5). Based on the early maps, a single story "L"-shaped structure was situated on this portion of the lot. Exposed segments of the structural foundation display construction methods and materials from the late 1800s overlain by early 1900s modifications. Exploratory investigations consisted of backhoe stripping and trenching and hand excavations. For ease of control, the site was separated into east and west areas, corresponding to the front north-south portion and the west wing and back yard portion of the structure, respectively.

After removing approximately 4 to 8 inches of gravelly fill, asphalt, and concrete in the eastern area, the foundation was exposed and followed out using a combination of backhoe and hand clearing. As indicated in Figure 5, the southeast, southwest, and northwest corners as well as portions of the east wall foundation and complete west and south wall foundations of the front section of the house were exposed. The eastern segments of the west wing wall foundation were also uncovered.

Controlled hand excavations were concentrated in a 5- x 20-foot area between the exposed east and west wall foundations, with the south wall delimiting excavation in that direction. About 10 inches of gravelly rubble fill was removed by backhoe to expose the dark grayish brown clayey deposits that represent an artificially buried in situ deposit. The excavations in this area bordered on the north and east of an exposed limestone chimney base (Fig. 8,a). Vertical control was maintained from a post set into the surface of the asphalt. The difference between the datum and actual asphalt surface was 6 inches, based on elevations recorded during the alidade and plane table mapping of the lot. All below-datum measurements for this area have been adjusted accordingly so that the vertical measurements are from the asphalt surface.

In the western area of the site paralleling the west wing of the house, initial exploratory backhoe excavations stripped away approximately 6 inches of overlying fill and asphalt from a 40- x 55-foot area. A backhoe trench 60 feet long, 35 inches wide, and 30 inches deep was dug into the exposed surface. Oriented east to west along the north side of the exposed surface, the trench was used to evaluate subsurface strata as a guideline for subsequent excavations. As a result of wall profiles, it was decided to remove another 10 inches of fill to expose an underlying activity surface thought to be associated with a sign painting shop. Thereafter, a 15- x 50-foot area (long axis east-west) was gridded with 5- x 5-foot squares. Two units within the grid, N105 W105 and N100 W125, were chosen to evaluate the distribution of artifacts being found in the east section of the lot. This was the primary reason for backhoe removal of another 10 inches of fill to expose the dark grayish brown clayey stratum in Unit N100 W125. Elsewhere on the lot, most importantly the east area of the site, this stratum had been found to contain late 1700 s and early 1800 s artifacts. Vertical control was maintained from the southeast stake of each unit. As the stakes were set into the exposed surface, the difference between datum elevation and that of the actual asphalt surface was measured at approximately 16 inches. Therefore, all elevations in the western area are +16 inches below the asphalt surface. For ease of description, each area will be dealt with separately.

\section{Eastern Area}

\section{Stratigraphy}

The stratigraphy was considerably different and less complex in the eastern area where later building modifications were laid over earlier construction. In the western area, several activity surfaces associated with the building's use were less easily defined. 


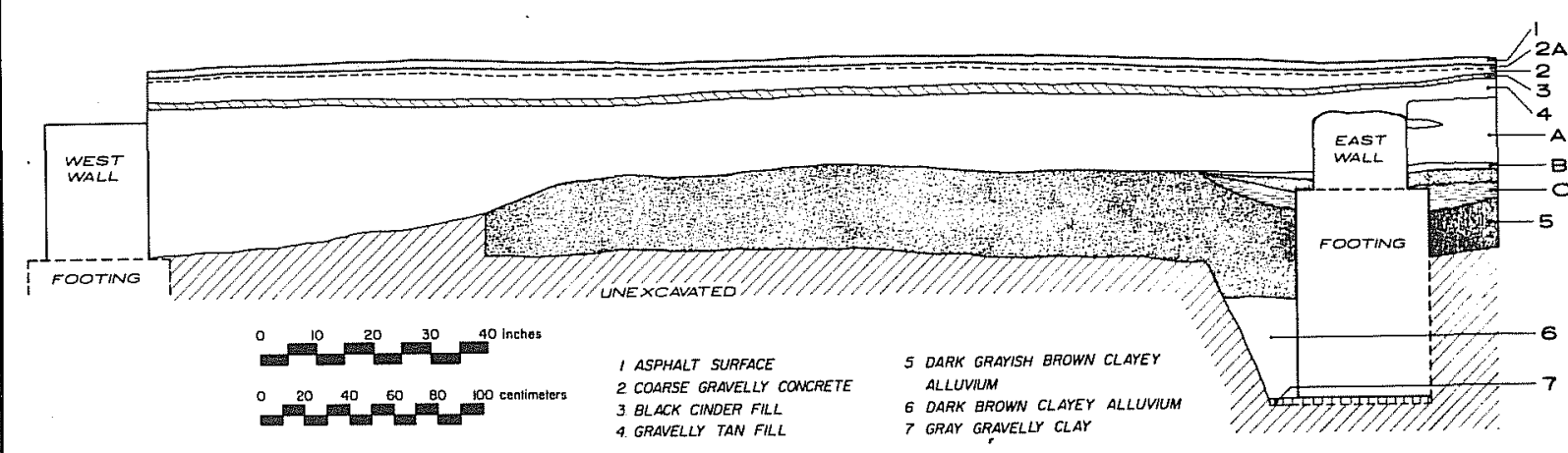

a
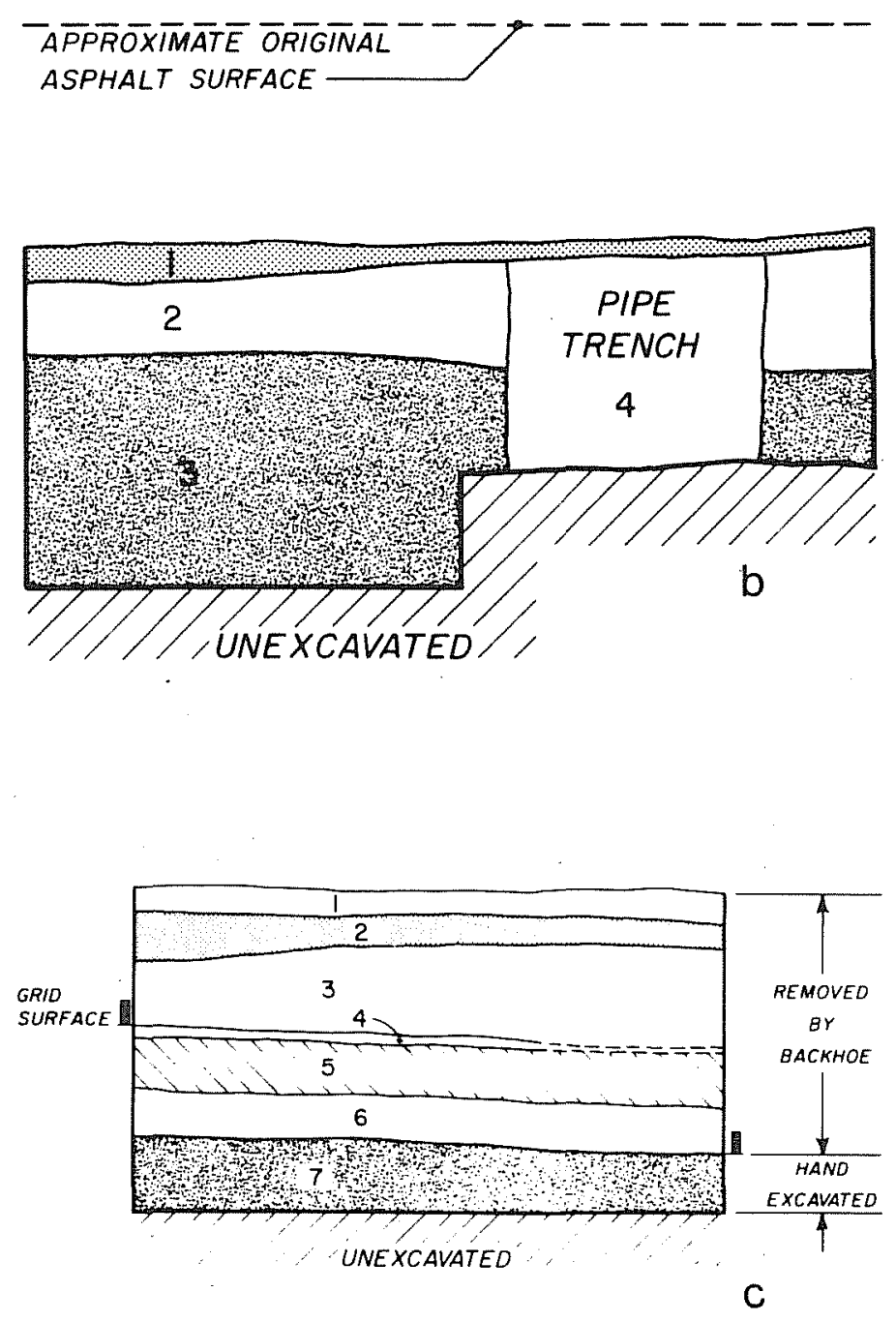

1 GRAYISH SANDY LOAM

2 YELLOWISH CALICHE FILL

3 DARK GRAYISH BROWN CLAY

4 DARK GRAYISH BROWN CLAY

WITH CALICHE INCLUSIONS

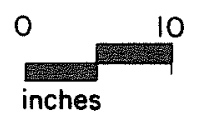

$0 \quad 10 \quad 20 \quad 30$

centimeters

Figure 8. Profiles of Units at $41 \mathrm{BX} 651$. a, north profile of excavation across chimney base (A, B, and C represent lenses of mortar and fill); b, west profile of Unit N105 W105; c, south profile of Unit N100 W125. 
The total area defined as the eastern area encompasses the front, or north-south, portion of the structure and a poured concrete slab bordering the southwest corner. Stratigraphy is based on the 20 -foot-long, north wall profile from the interior subfloor excavations between the east and west wall foundation remnants (Fig. 8,a). Except for Strata 5, 6, and 7 which are considered natural soil deposits, the remainder are borrowed fill used to support two artificial surfaces. These surfaces are a result of modifications superimposed onto the main structure. A brief summary of each follows.

Stratum 1 was a 2-inch asphalt surface used to pave the entire lot for use as a parking lot.

Stratum 2 was a 3 -inch coarse, gravelly concrete slab with yellow and salmon-colored brick fragment inclusions and a smoothed surface similar to the slab west of the foundation. It appeared that this stratum was laid over the underlying fill and the old wall foundations after the original east wall had been razed and replaced with brick, probably after 1927 when the property became a commercial building.

Stratum 3 was 1 inch of cinder fill.

Stratum 4 was a 13- to 26-inch-thick gravelly tan fill used to level the area between the foundation walls on the east and west to support the concrete slab. The thickest portion lay to the west where the underlying stratum slopes in that direction. Fill content was mainly rubble from demolition; large pieces of limestone about 12 inches in length, window glass, ceramic insulators, and plaster were dispersed throughout with a noticeable concentration of red brick fragments, red sandstone pavers, and plaster in the thickest portion on the west.

As Strata 1-4 represented intrusive deposits, they were removed to expose the natural soil deposits below.

Stratum 5 was the dark grayish brown clayey soil that apparently underlies most of Lot A24. In Unit N110 W100 at 41 BX 649, this was Stratum 3. At 41 BX 650, it was overlain by 6 inches of fill and asphalt. Two measurements are given, one for thickness and one for depth below datum. The former is based on a color change observed in the profile of a sondage pit excavated along the inside of the east wall. The purpose of the pit was mainly to plumb the depths of the footing (Fig. 8,a). Thickness of the stratum in the pit profile was 23 inches.

Excavations in a 32- $x$ 58-inch area on the north side of the chimney base began at 17 inches below datum ( 11 inches below the surface) and ended at 29 inches below datum ( 23 inches below the surface). On the east side of the chimney base, a 60- x 60-inch area was excavated from 14 to 33 inches below datum ( 8 to 27 inches below the surface). The upper 5 inches was a remnant of the overlying fill not removed by the backhoe. Except to clear off remnants of Stratum 4 fill and to expose the surface of Stratum 5, the 60- $x$ 32-inch area west of the chimney was not excavated. In this area, the surface of the stratum sloped west with a drop in elevation of approximately 13 inches. As no controlled vertical levels were utilized, excavations ceased as artifact content ceased. As a result, only the upper 12 inches of matrix on the north and the upper 14 inches east of the chimney were excavated. The artifacts from excavations in the subfloor area predate the purported construction of the structure by at least 20 to 30 years, the majority dating from the late 1700 s and early 1800 s.

Stratum 7 was a gray gravelly clay found at the base of the footing in the bottom of the sondage pit west of the east wall. No thickness is given as only the surface of the stratum was examined. The surface of the stratum measured 63 inches below datum, and it contained no artifacts.

Small lenses of mortar and fill were exposed on either side of the east wall. The lenses, labeled A, B, and C in Figure 8,a, are probably the residue from footing and foundation construction and would therefore indicate the level from which this was constructed. 


\section{Structural Features}

Structural features at $41 \mathrm{BX} 651$ East indicated one phase of primary construction and at least two phases of modification which overlay and altered the primary construction and at the same time used it for support. Additions to the primary construction also enlarged the enclosed area of the building. The majority of the structural features were located in the eastern area of the site where the main portion of the house was situated. The construction date has been estimated at ca. 1868, with probable additions made between 1882 and 1898 when the house was occupied by the Thaddeus Smith family. Later modifications and additions probably occurred after the property became commercial in 1927 . Though the exact date of the modifications and additions is hard to determine, the sequence of primary construction and later modification can be traced from the results of the excavation at the site.

\section{Primary Construction, ca. 1868 to 1882}

Excavations in the interior of the southern portion of the structure indicated a squared-off limestone and mortar footing, 24 inches in width, supported the foundation. The footing depth, measured at the inside of the east wall exposure, was approximately 40 inches into Strata 5, 6, and 7. The top of the footing was level with the grade surface of Stratum 5 (the ground surface at that time) so that the elevation of the west footing surface was lower by 13 inches than the surface of the eastern footing (Fig. 8,b). The footing was exposed along the inside of the west, south, and east walls and the outside of the east wall.

Centered atop the limestone footing was an 18-inch-wide wall foundation. The foundation was constructed of cut limestone set with a yellow lime and sand mortar. Cut marks indicate carefully squared surfaces on the inside and outside faces. The narrower width of the wall foundation left a 3 -inch lip on either side of its contact with the footing.

The remnant of wall found atop the foundation along the south wall measured 13 inches in width. The exterior of the wall remnant was flush with the exterior of the foundation. This left a 5-inch interior lip atop the wall foundation, probably used to support the floor joists. The exterior surface of the wall remnant and foundation was faced with cement plaster.

The wall foundations were followed out so that the upper portion of the west and south walls were exposed. Junctions, intersecting corners, and the concrete overlay indicated additions and modifications attributed to secondary construction.

Although no direct evidence was discovered for it during the excavations, a small detached kitchen can be seen on the northwest side of the house in an 1873 map (Koch 1873) of the area. The remnants of the kitchen were probably destroyed during later construction of the west wing addition.

\section{Secondary Construction and Modifications, ca. 1882 to 1958}

Later additions to the original structure include the west wing portion of the " $L$ " probably built during the Thaddeus Smith occupation of the house (1882-1898). Evidence for this additional construction is based on the junction of the west wing walls with the west wall of the main structure and comparison with the 1896 Sanborn insurance map (Fig. 3). Here, instead of being integrated with the west wall, there was a butt joint with a wall of similar construction and material. Along the west wall between the west wing corners was a 4-foot-wide doorway (see Fig. 9,a,b). On the west and directly butted against the lower west wall lay a 1-x 2 -foot pad of red brick. Its location and worn surface suggest an external tread outside the door leading to the kitchen before the west wing was added. The location of the tread suggests that the doorway had French doors similar to those shown in a photograph of a mid-19th-century house at 318 North Flores Street (see Kendall and Perry 1974:Fig.4), with only one of the doors customarily used.

Later modifications to the structure in the early 1900 s are evidenced by a layer of concrete (Stratum 2) poured over the interior area of the main portion of the house. Remnants of a poured concrete wall foundation 


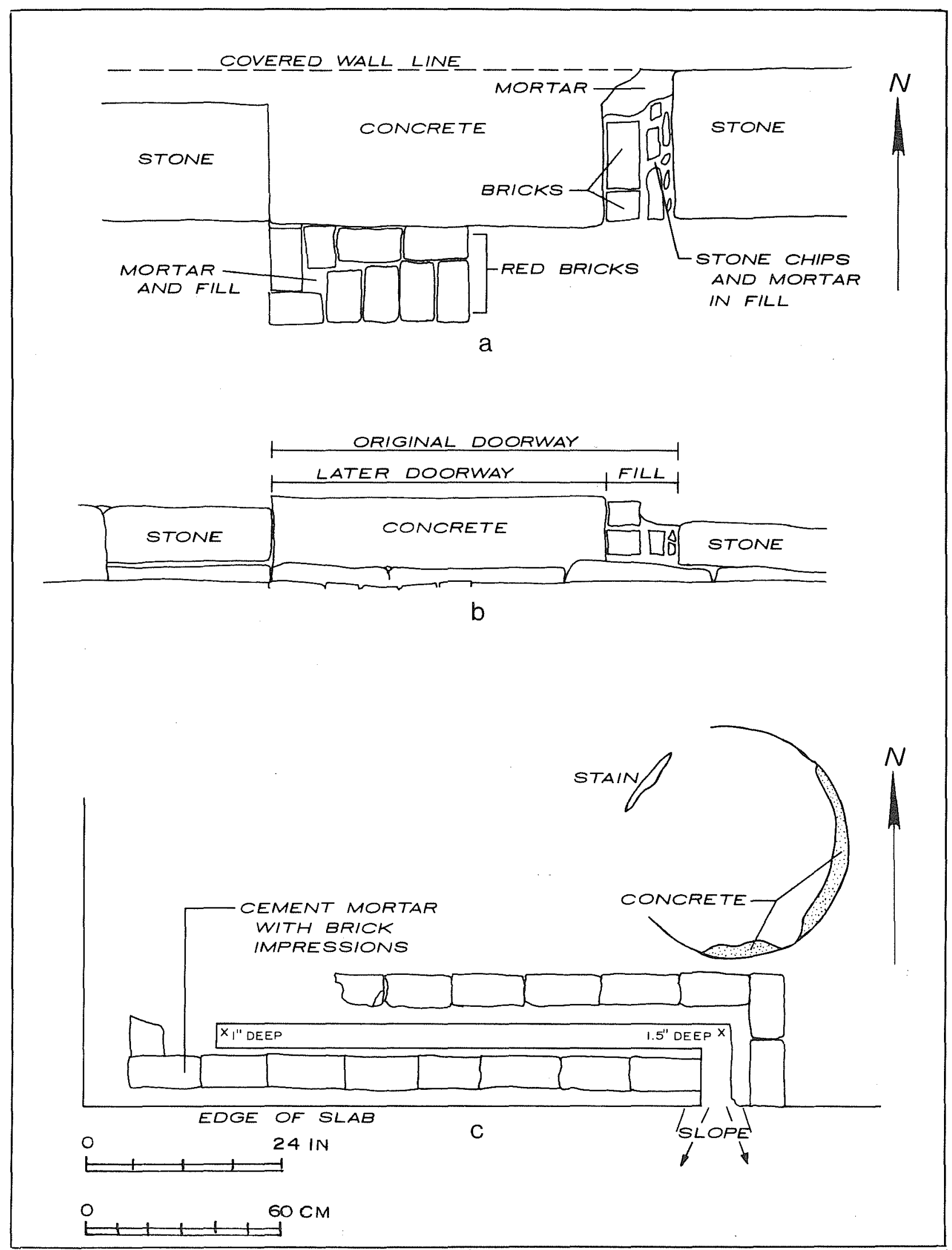

Figure 9. Construction Details at $41 B X 651$. a, top view of doorway; b, side view of doorway; c, plan of drain feature on slab. 
butted up against the southeast corner to widen the house to the east, and observations from profiles suggest that the concrete slab was poured during a modification of the east side of the structure. Apparently, the front porch and east wall were razed, the wooden floor was removed, and accumulated demolition fill was pushed into the subfloor area as leveling fill for the slab. At the same time, the before-mentioned doorway on the west wall was narrowed to 3.5 feet, the correct size to install a 3-foot interior door for a commercial establishment.

It is possible that the 17- $\mathrm{x}$ 14-foot concrete slab that butted onto the southwest portion of the west wall was added about the same time or soon after. An "L"-shaped channel 5 feet long, 3 inches wide, and 1 to 1-1/2 inches deep cut into the surface on the southwest corner of this slab (Fig. 9,c), appears to have been used as a drain from the interior to the exterior of the area. The channel was brick lined, only traces of the bases of one row of brick on either side remain. North of the drain lies a circular impression in the slab surface approximately 2 feet in diameter. The two features were probably associated during the commercial use of the building.

The last and final modification to 409 North Flores Street came in 1958 when all buildings on Lot A24 were demolished and covered with a caliche and gravel fill overlain by an asphalt surface. Thereafter, the lot was used for parking.

\section{Western Area}

The western area is defined as the scraped area west of the concrete pad. Included within the area are Backhoe Trench 1 (BHT 1), Unit N105 W105, and Unit N100 W125. BHT 1 documented the subsurface after 6 inches of fill and asphalt had been removed. The hand-dug units document the subsurface after an additional 10 inches and 20 inches of fill had been removed.

\section{Stratigraphy}

The stratigraphy for the western area is based on the south wall profiles from BHT 1 and Unit N100 W125 (Fig. 8,c) and the west wall profile from Unit N105 W105 (Fig. 8,b). Including the asphalt surface, seven strata were identified. Six of these were considered artificial. Based on thickness of the fill in three profiles, a definite north and west slope to the natural clayey surface required more fill in some areas than others to level the surface for use. Except for the recent asphalt surface, most of the used surfaces appeared to have been hard-packed dirt.

Stratum 1 was the 2 -inch-thick asphalt surface.

Stratum 2 was a 4-inch-thick gravel and caliche fill used as a base for the asphalt.

Stratum 3 was a light grayish brown sandy loam fill. Quantities of limestone fragments five or more inches in length were dispersed throughout the matrix. In Unit N100 W125, a good representation of the stratum measured between 6 and 10 inches in thickness with the thickest portion to the west. In BHT 1, the stratum measured approximately 10 inches in thickness. In Unit N105 W105, Stratum 3 was removed during backhoe work. In BHT 1, the upper levels of the stratum nearest the northwest corner of the concrete slab contained a temporally mixed trash accumulation of bottles, metal scraps, and bone. Given the elevation of the trash deposit at the contact with Stratum 2 and corresponding with the level of the slab, it was probably an accumulation from later commercial use of the building. The manufacturing technique of many of the bottles indicate a 20th-century date of manufacture, while others appear to date from the late 19th century.

Stratum 4 was an 1-inch-thick, hard-packed surface. In Unit N100 W125, it was whitish in color, whereas in BHT 1, it was stained a blue green which led researchers to believe that it was an activity surface associated with commercial use of the property as a sign painting shop. The stratum was not present in Unit N105 W105 due to removal by the backhoe. No artifacts were observed or collected from the stratum. 
Stratum 5 was a dark grayish brown clayey soil with charcoal mottles and brick fragments dispersed throughout the matrix. Thickness varied with location. To the south, in Unit N100 W125, it measured 5 inches in thickness. Due north of the unit, in BHT 1, it was 6 inches thick. The largest variation in thickness was observed in the south wall profile of BHT 1 . Here the thickness varied from east to west, which followed the natural slope. On the east it averaged 2 inches, and on the west it averaged 6 inches in thickness. In Unit N105 W105, only 1 to 3 inches of the stratum remained. This represented the lower portion of the stratum. Artifacts from that unit include ceramics, glass, bone, and metal objects.

Stratum 6 was yellowish gravel and caliche fill. Variation in thickness from south to north is based on profiles from Unit N100 W125 and BHT 1. In Unit N100 W125, Stratum 6 was 5 inches thick. Due north in BHT 1, Stratum 6 was 18 inches thick. The profile from the west wall of Unit N100 W125 served to corroborate the slope (Fig. 8,b). At the south end, the stratum was 5 inches thick, while at the north end it measured 9 inches. Both variations are indicative of the south to north slope of the underlying natural soil horizon. No artifacts were found in this stratum during excavations in Unit N105 W105. This unit is the only unit in which this stratum was hand excavated.

Stratum 7 was the dark grayish brown clayey soil horizon underlying the lot. At 41 BX 649, it was Stratum 3; at $41 \mathrm{BX}$ 650, though higher in elevation, it was Stratum 3. In the eastern area of the lot, it was Stratum 4. All were the same type of soil, the only difference being the amount of overlying fill. In each excavation, the upper 10 or 12 inches of the stratum was found to contain the majority of artifacts.

All of the following measurements were taken from the exposed ground surface and represent depth below datum. In Unit N105 W105, excavations of the matrix were from 9.5 inches to 14 inches over the whole unit and 14 to 23 inches in the southwest quadrant. The measurements comprise Levels 2 and 3 in that unit. In Unit N100 W125, excavations were from 10 to 16 inches and from 16 to 20 inches. The measurements comprise Levels 2 and 3 in that unit. Excavations ceased in each unit when artifacts noticeably decreased. Artifact frequency in Unit N100 W125 was noticeably lower than in other units on the lot. Ceramics from both levels were predominantly from the early 1800s. Bone, glass, and metal pieces were also present but not in quantity. In Unit N105 W105, the Level 2 ceramics were mostly post-1850 with a couple of earlier pieces. Glass from the same level dates from 1827 onward. The bone weight counts from the level were higher than anywhere else on the site. Level 3 contained lower quantities of material, including ceramics from the early 1800 s.

\section{Features}

Features in the western area appear to be late additions associated with commercial use of the property. Only two features were identified.

Feature 1 was composed of six rows of irregularly spaced cedar post remnants and postholes (Fig. 5). The tops of the posts were exposed during the removal of the 6 inches of asphalt and fill. After the subsequent 10 inches of fill was removed, the posts were mapped. They were concentrated in a 15- x 15-foot area extending west from the west edge of the concrete slab. About $30 \mathrm{feet}$ west of the slab was a single post located in the middle of Unit N100 W125. The top of the post was approximately 21 inches below the Stratum 3 surface. The bottom of the post was 2 inches into the surface of Stratum 7. In all, 30 posts and postholes were counted. Their function appears to have been as support for a wooden platform extension, possibly used as a loading dock.

Feature 2 was a clay drainage pipe and trench. The pipe and trench were first observed in the south wall of BHT 1 about 10 feet from the east end (Fig. 5). The trench had been dug from the Stratum 4 surface, and appeared to angle to the southeast. This was later supported by the discovery of the same trench in Unit N105 W105. The trench ran northwest toward BHT 1 and southeast toward the southwest corner of the concrete slab. In Unit N105 W105, the trench had also been dug from the surface of Stratum 4. Fill within the trench was a dark grayish brown clayey soil similar to that in Stratum 7. Artifacts found within the trench matrix include a couple of ceramic sherds, unidentifiable metal scraps, five nails, a small quantity of bone, and several pieces of glass. Based on the angle of the trench and the level from which it was dug, it could 
have served as a drain for the house at 403 North Flores Street (41 BX 650) or for 409 North Flores Street (41 BX 651) during the commercial phase when that particular surface was being used by a sign shop.

\section{ARTIFACT ANALYSIS}

\section{METHODOLOGY}

All artifacts recovered during the testing were cleaned, labeled, and cataloged according to standard laboratory procedures and will be curated, along with all field notes, photographs, drawings, and catalog sheets, at the laboratory of the CAR. The artifacts were separated into categories that would reflect their use and/or purpose for being present on the site (Table 1). The general categories were chosen to give an overview of the types of activities represented.

Special attention was paid to the ceramic sherds in the collection (Table 2), since they can provide important information on dating and comparative family income.

The animal bone was sent to William McClure for analysis. We asked him to tell us what animals were represented and whether there were any significant differences between fauna by site.

\section{KITCHEN/DINING/HOUSEHOLD ITEMS}

The kitchen/dining/household category includes anything pertaining to the storage, preparation, and consumption of food, and any object related to the operation of a household.

\section{Ceramics}

In Table 2, a detailed breakdown of the various types of ceramics recovered is arranged more or less according to dates when they were popular in San Antonio.

Unglazed ceramics in San Antonio consist of two basic types (Ivey and Fox 1981:31). Goliad (Fig. 10,a) is a bone-tempered, hand-built ware made first by the mission Indians and apparently traded or sold by them in town, for sherds of this type are found in all sections of town in 18th-century contexts. The second type of unglazed ware is wheel-made and higher fired than the first. It may also have been a local product.

Burnished wares in 18th-century sites in Texas are generally of two types. Sherds of a redware created by selective burnishing in designs over the surface come from a peculiarly shaped bowl form with a deeply indented base (Gilmore 1974:63). A gray- to tan-bodied ware, probably from Tonalá, Jalisco, has slipped surfaces often decorated in shades of red and black and highly burnished. Four such sherds from 41 BX 649 have a red slip inside and out, with only the outside surface burnished.

A variety of lead-glazed utility wares was available in 18th-century San Antonio. A thin-walled, red-bodied variety called Galera ware (Fig. 10,b,c) was mold-made and decorated with brown, cream, and green floral designs (Ivey and Fox 1981:34). Reconstructed vessels have revealed that this type of pottery was primarily used as small pots for making hot chocolate and for cooking. A heavier, sandy paste variety (Fig. 10,d) was wheel-made into bowls and large ollas, sometimes decorated with a green band around and over the rim (Fox 1974:56). Sherds from these vessels appear orange to yellow orange, or dark green.

Earthenwares with tin added to the glaze (Fig. 10,e-h) to make a white, opaque background for bright enamel designs were brought to San Antonio from Mexico. At first made predominantly in Puebla and Mexico City, by the late 18th century they were made in numerous other pottery centers in Mexico. This pottery type is particularly useful to the archaeologist because the designs changed with time, giving clues for dating site 
TABLE 1. ARTIFACT PROVENIENCE

$41 \mathrm{BX} 649$

$41 \mathrm{BX} 651$

$41 \mathrm{BX} \quad 650$

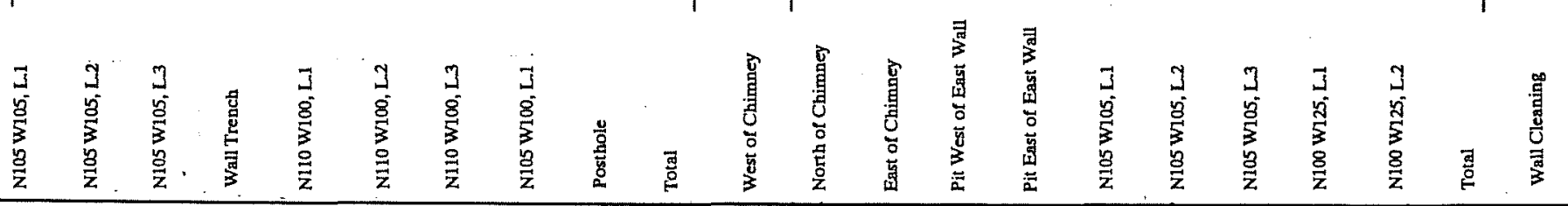

Kitchen/Dining/Household

Unglazed Ware
Burnished Ware
Lead-glazed Ware

Tin-glazed Ware
Decorated Whiteware
Undecorated Whiteware

Basalt
Lusterware

Yelloware

Stoneware

Glass Containers

Caps

Copper/Brass
Tin Can Scrap

Iron Scrap

Tableware

Shell (grams)
Flower Pot

Clothing/Personal/Aativities

Buttons, Bone

Buttons, Shell

Buttons, Ceramic

Jewelry and Beads

Comb Fragments

Brass Pin

Coins

Clock Winding Stem

Spring

Slate Pencil

Workshop

Barn/Shop Hardware
Wire

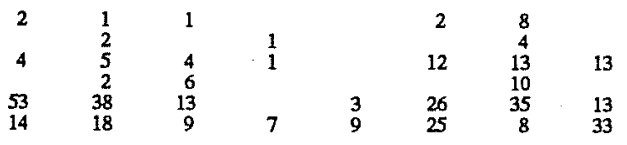

$\begin{array}{rrr}14 & & \\ 7 & & \\ 52 & & \\ 18 & & \\ 181 & 2 & 13 \\ 123 & 1 & 12\end{array}$

$\begin{array}{rrr}1 & 10 & \\ 3 & 2 & \\ 8 & 33 & 1 \\ 3 & 32 & 1 \\ 5 & 27 & 1 \\ 2 & 25 & 1 \\ 1 & 2 & \\ & 1 & \\ 2 & 1 & \\ 53 & 120 & 3 \\ & & \\ 7 & 39 & \\ 3 & 6 & 1 \\ 1 & 8 & \\ & 1 & \end{array}$

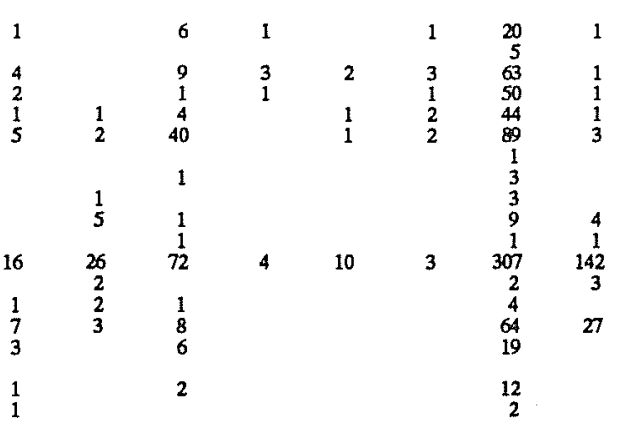

Gunflints

Percussion Caps

Construction

Window Glass

Wire Nails

Hardware

Brick
Plaster
Slate

Prehistory

Chert Fragments
Chert Anifacts
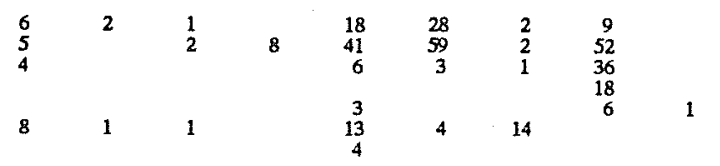

66
169
50
18
10
41
4

$\begin{array}{ll}2 & 30 \\ 2 & 5 \\ 2 & \end{array}$

$\begin{array}{rl}30 & \\ 56 & 1 \\ 6 & \\ 4 & \\ 10 & \\ 2 & \end{array}$

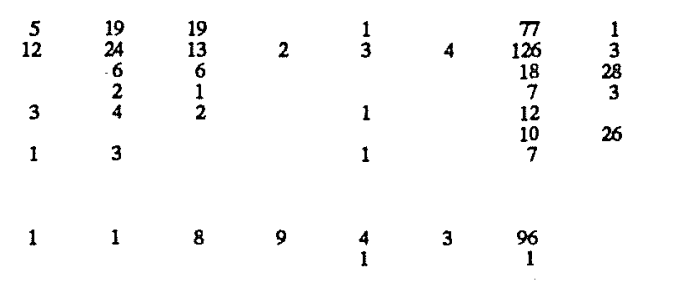


TABLE 2. PROVENIENCE OF CERAMICS

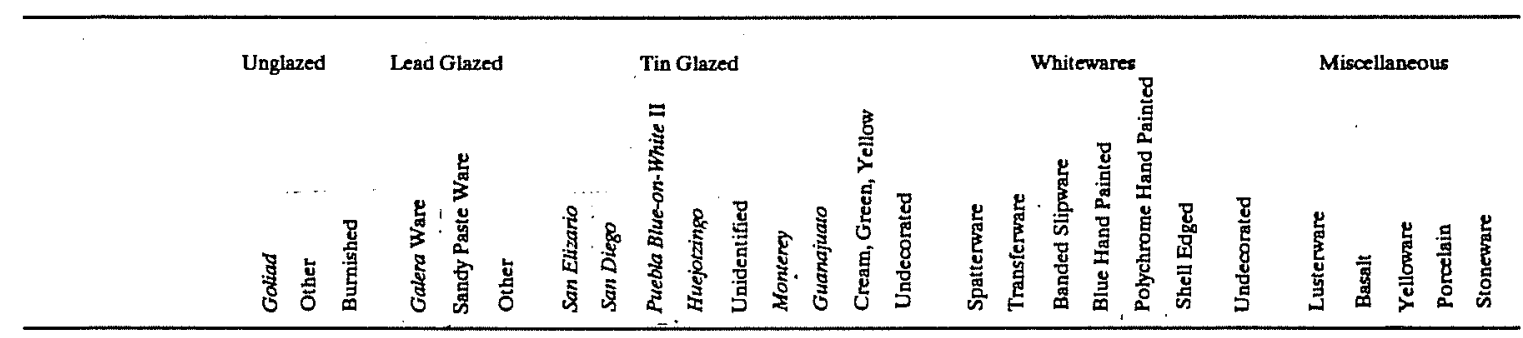

\begin{abstract}
$418 \times 649$

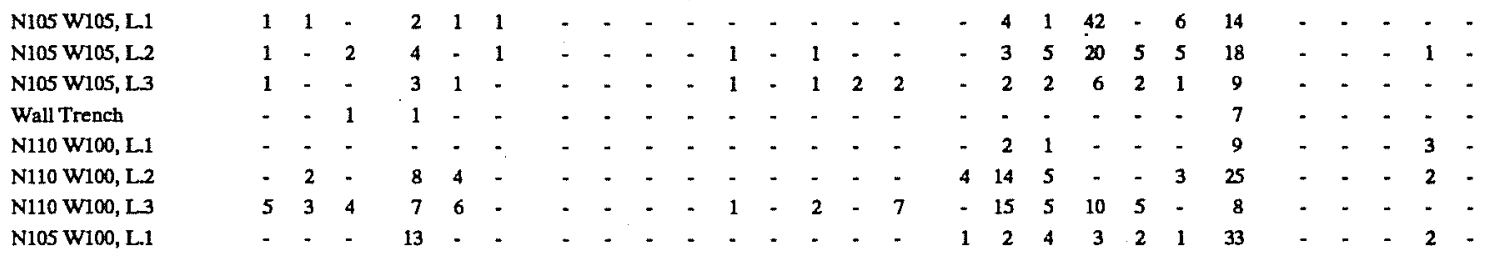

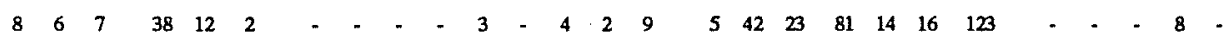

$\underline{41 \mathrm{BX} 651}$

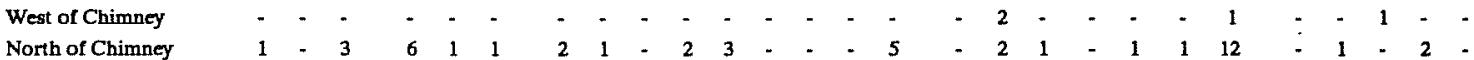

$\begin{array}{lllllllllllllllllllllllllllllllllllllllll}\text { East of Chimney } & 5 & 5 & 2 & 24 & 8 & 1 & 8 & 1 & 6 & - & 1 & 5 & 1 & - & 10 & 1 & 7 & 8 & 4 & 3 & 4 & 25 & 2 & - & 1 & 1 & -\end{array}$

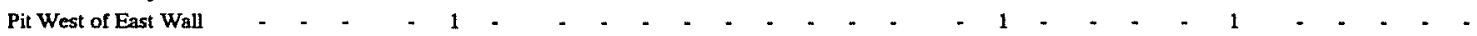

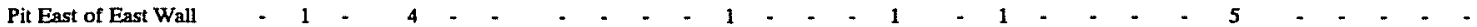

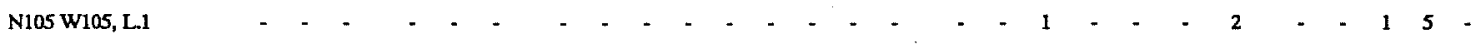

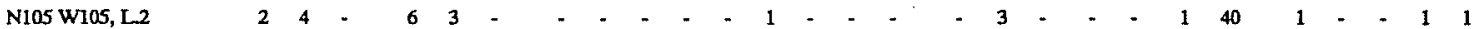

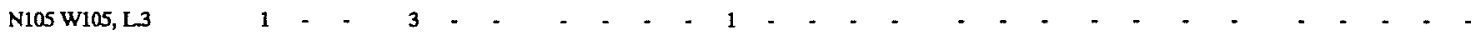

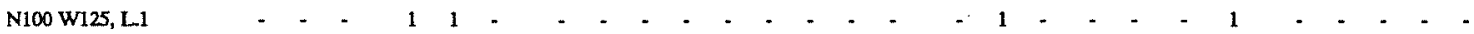

$\begin{array}{llllllllllllllllllllllllllllllll}10 & 10 & 5 & 45 & 16 & 2 & 10 & 2 & 6 & 2 & 6 & 6 & 1 & - & 17 & 1 & 17 & 11 & 4 & 5 & 6 & 89 & 3 & 1 & 3 & 9 & 1\end{array}$

$41 \mathrm{BX} 650$ 


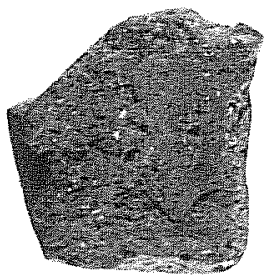

a

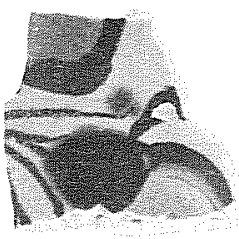

e
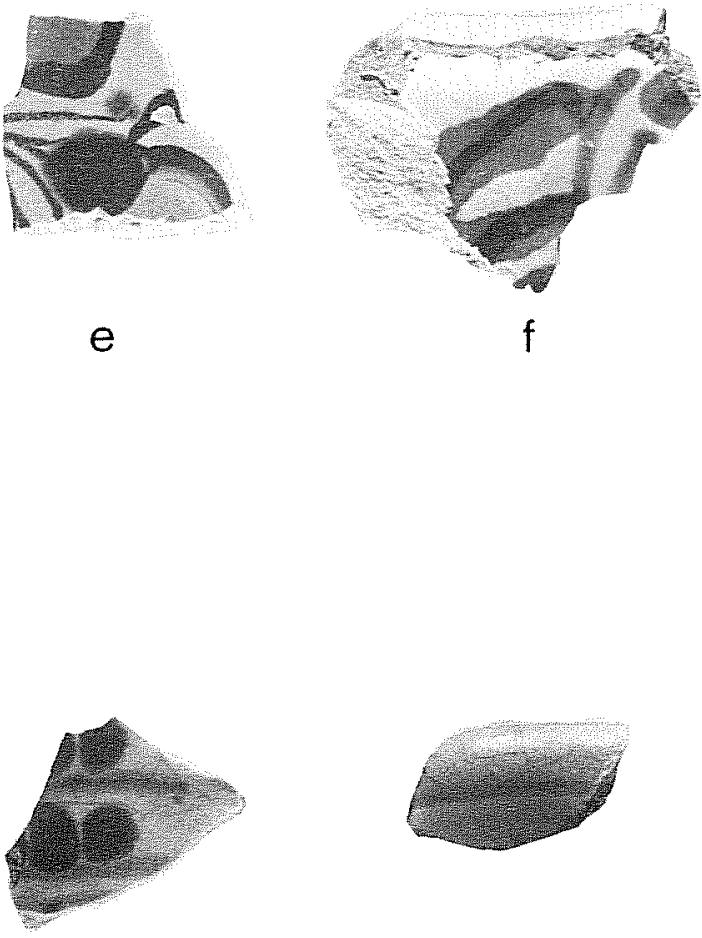

f

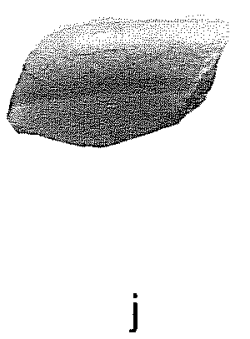

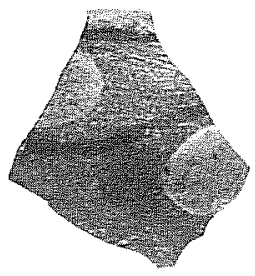

C

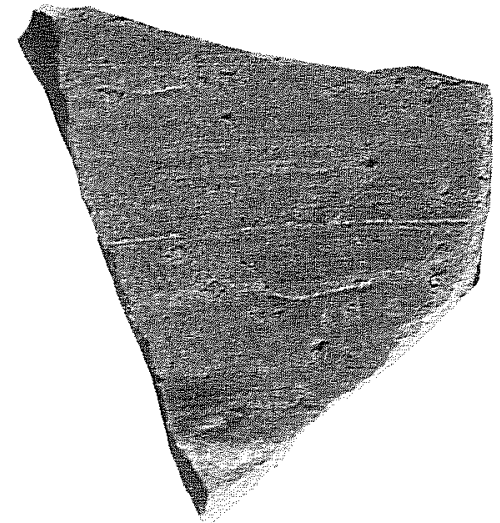

d

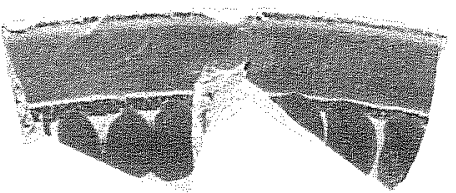

g
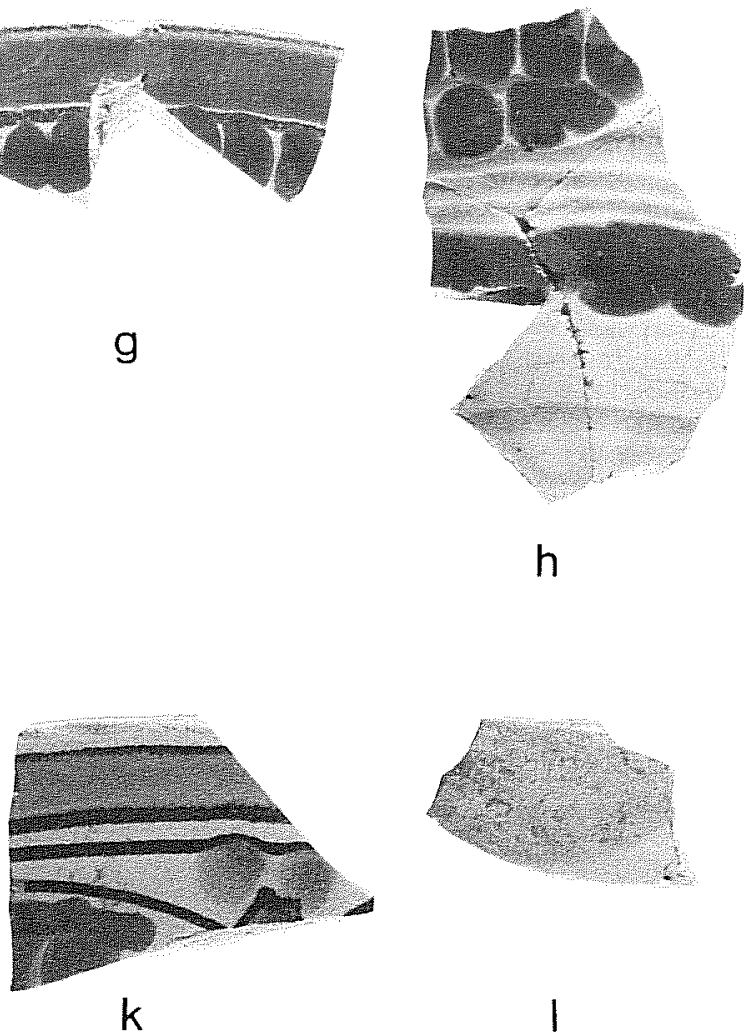

h

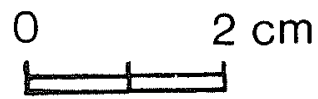

Figure 10. Unglazed, Lead-Glazed, and Tin-Glazed Wares. a, Goliad ware, 41 BX 651; b, c, Galera lead-glazed ware, 41 BX 649; d, sandy paste, lead-glazed ware, 41 BX 651, e, San Diego Polychrome majolica, 41 BX 651; f, Monterey Polychrome majolica, 41 BX 651; g, San Elizario Polychrome majolica, plate form, 41 BX 651; h, San Elizario Polychrome majolica, chocolate cup form, 41 BX 651; i, Puebla Blue-on-White II majolica, 41 BX 651; j, Huejotzingo Blue-on-White majolica, 41 BX 651; k, Guanajuato majolica, 41 BX 651; 1, cream, green, and yellow majolica, 41 BX 649. 
deposits. Dates for these various patterns of decoration have been derived through comparisons of the collections from numerous archaeological sites whose dates of occupation are known (see Table 3).

TABLE 3. DATES FOR MAJOLICA PATTERNS

Name of Design

San Elizario (Fig. 10,g,h)

San Diego Polychrome (Fig. 10,e)

Puebla Blue-on-White II (Fig. 10,i)

Huejotzingo (Fig. 10,j)

Monterey Polychrome (Fig. 10,f)

Aranama Polychrome

Guanajuato (Fig. 10,k)
Approximate Date

Sources

The early 19th century brought a change in household ceramics from Mexican-made tin and lead-glazed wares to white paste earthenware from England (Figs. 11,a-h; 12,a-f). These were decorated in a variety of techniques in bright, primary colors (for detailed descriptions see Davis and Corbin 1967 and Fox 1986:111-123). Fragments of yellow paste earthenwares, luster decorated earthenwares, and stoneware bottles are also of British/European origin. A fragment of the handle of a black basalt ware tea pot or pitcher (Fig. 12,g) probably dates from the early 1800 s (Godden 1975:151-152).

Undecorated sherds in the collection may represent portions of earthenware or ironstone vessels with molded designs that became popular after 1850 in this area. Maker's marks recovered on these wares are from Homer Laughlin, 1879-1897, East Liverpool, Ohio (Barber 1904:110), and J \& G Meakin, 1851 to the present, Hanley, Staffordshire, England.

Porcelain sherds recovered were for the most part too small to identify. Fragments of a Chinese decorated overglaze porcelain rice bowl (Fig. 12,h) may be from an early 20th-century restaurant operation at $41 \mathrm{BX} 651$.

\section{Glass Containers}

The glass fragments excavated from all three sites were essentially the same assortments of brown whiskey or beer, aqua soda, aqua and clear medicine, and olive wine bottles. In the Spanish colonial context at $41 \mathrm{BX} 651$, beneath the building, there was a pale blue green hand-blown pontil medicinal vial (Fig. 13,a) represented by a basal sherd. Similar ones are occasionally found in other colonial deposits in San Antonio. The rim of a similar vial came from the early deposits at 41 BX 649 (Fig. 13,b). From these same deposits came fragments of a pale green cathedral bottle (Fig. 13,c). A few clear, thin fragments from both sites probably represent lamp chimneys. Pieces of a fancy dark blue pressed glass vase or compote (Fig. 13,d) were found in Level 2 at 41 BX 651.

Among the numerous small glass fragments found while cleaning the foundations at $41 \mathrm{BX} 650$ were several whole and nearly whole aqua soda water bottles. These came from around the south tower foundation, perhaps left there by workmen when the house was under construction. Two of these bottles bear the mark "OCHS \& ASCHBACHER/SAN ANTONIO,/TEX," and used a spring or Hutchinson stopper patented in 1879 (Munsey 1970:104). Lorenz Ochs and George Aschbacher were in the bottling business in San Antonio from 1890 until Mr. Ochs' death ca. 1897 (City Directories 1890-1897). Three other soda water bottles are 


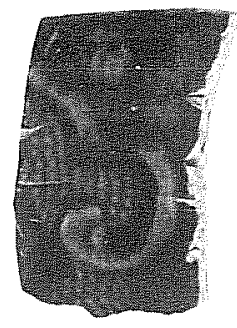

a (1) $\sqrt{2}$

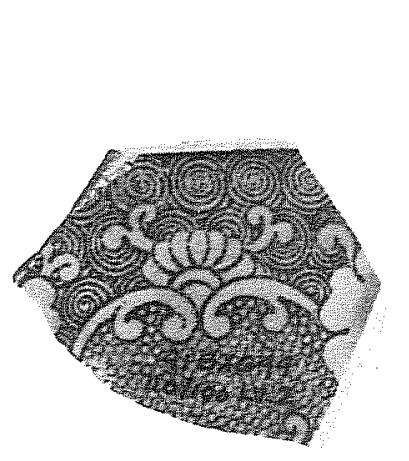

e

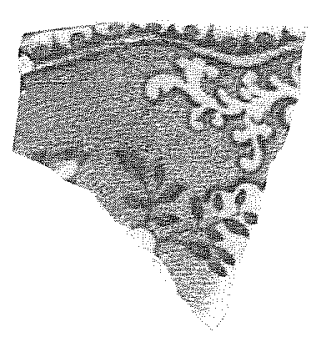

$\mathrm{b}$

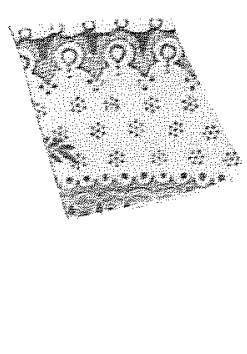

$\mathrm{C}$

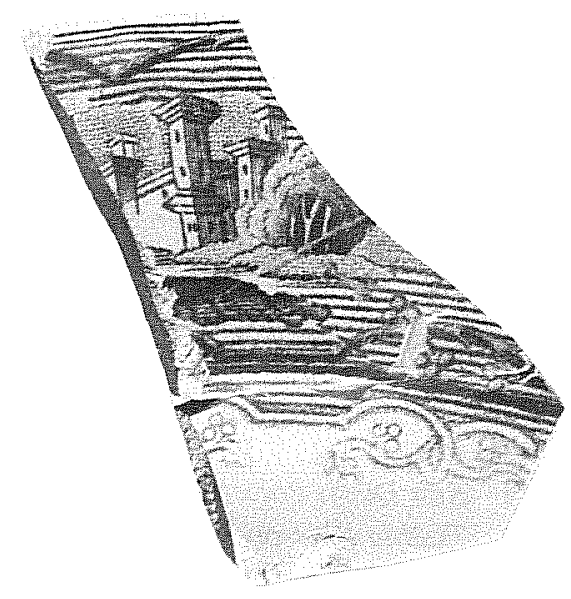

d

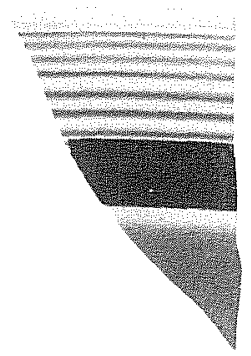

g

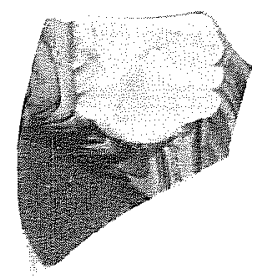

h

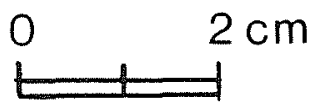

Figure 11. Whitewares. a, dark blue transferware, 41 BX 649; b, blue transferware, 41 BX 651; c, mulberry transferware, $41 \mathrm{BX} 649$; d, brown transfer on ironstone, $41 \mathrm{BX} 651$; e, polychrome paint over black transfer, 41 BX 649; f, red spatterware, 41 BX 651; g, h, banded slipware, 41 BX 649.

labeled "THE BEE CANDY/MFG CO./SAN ANTONIO/TEX," and have a crown cap closure. The crown cap or crown cork was patented in 1891 by William Painter of Baltimore (Munsey 1970:105). Both types of bottles have the mark "I.G.CO." on the side near the base. The crown cap bottles in addition have "99" after the mark. These bottles may be the product of the Illinois Glass Company of Alton, Illinois, in operation from 1873 to 1929 (Toulouse 1971:264), or the Ihmson Glass Company of Pittsburgh, Pennsylvania, in operation from 1855 to 1896 or later (Toulouse 1971:261). An ink bottle (Fig. 13,e) from the same general location, is marked "S.M.CO." on its base, a mark not identified so far.

\section{Metal}

Metal caps recovered were crown caps for soda water and white metal screw-on caps for later glass containers. All were from the upper levels.

Various fragments of unidentifiable scrap metal came from the upper levels in all sites. Most of this was thin, tin can type material. 


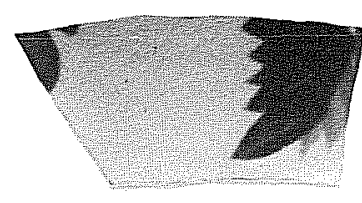

a

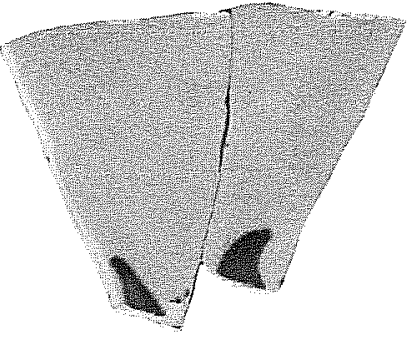

b

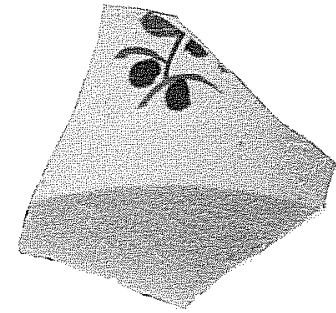

$\mathrm{C}$

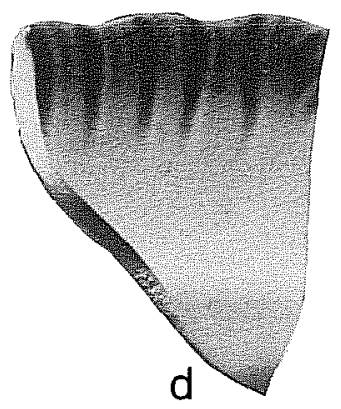

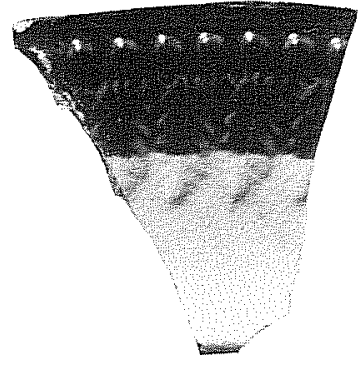

e

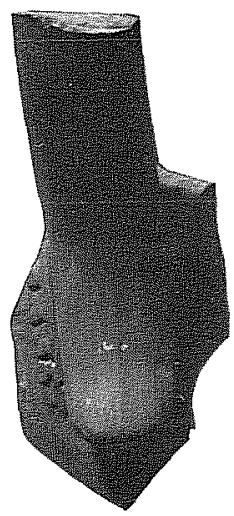

g
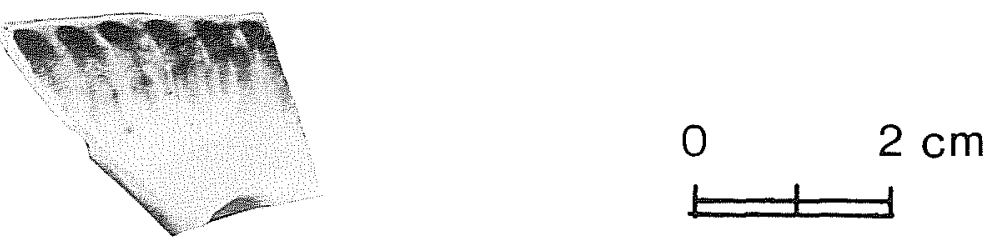

f

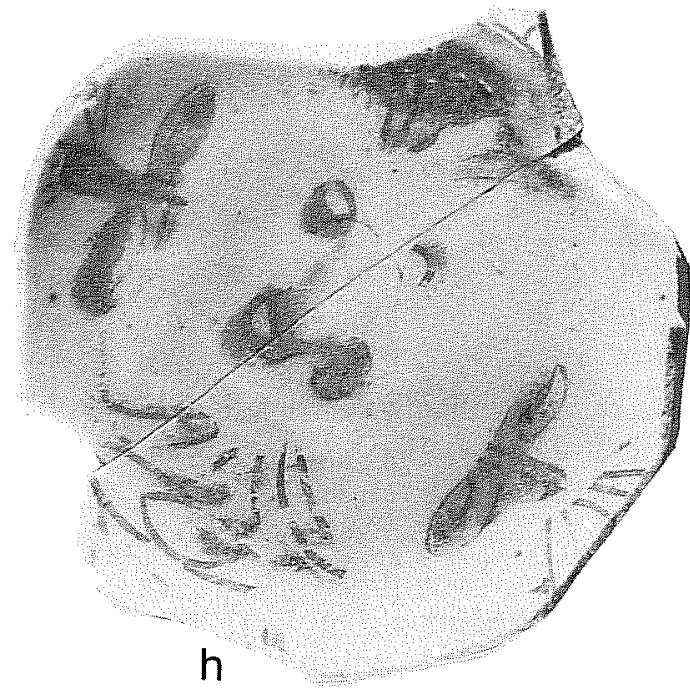

Figure 12. Whitewares, Basalt Ware, and Porcelain. a, blue hand-painted ware, 41 BX 649; b, blue handpainted ware, impressed mark, "DAVENPORT" and "HEN(DERSON \& GAINES/IMPORT(ERS)/NEW ORLEANS," 41 BX 649; c, hand-painted ware, Davenport, ca. 1836, 41 BX 649; d, green shell-edged ware, 41 BX 649; e, blue-edged ware, 41 BX 649; f, blue shell-edged ware, 41 BX 651; g, black basalt ware, $41 \mathrm{BX} 651$; h, Chinese porcelain, $41 \mathrm{BX} 651$. 


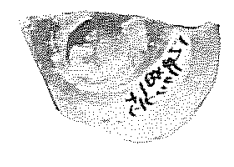

a

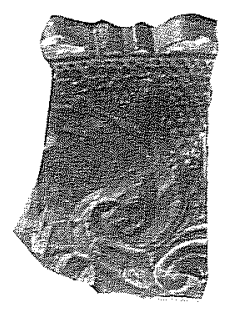

d

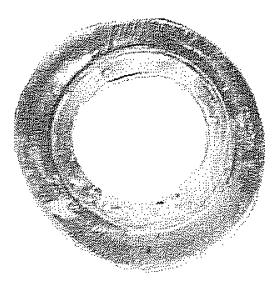

b
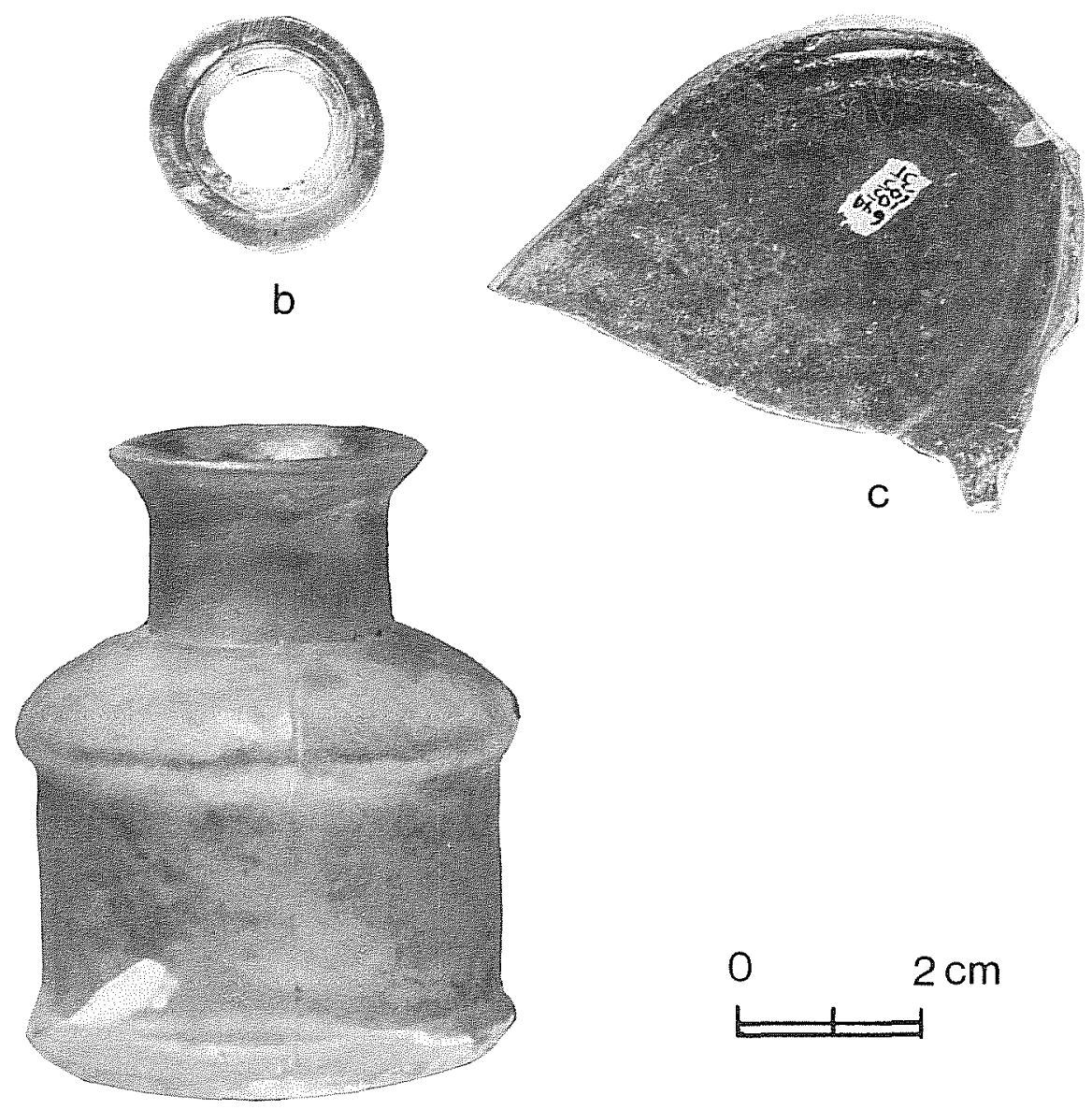

Figure 13. Glass. a, medicine vial rim, $41 \mathrm{BX} 649$; b, medicine vial base with pontil mark, $41 \mathrm{BX} 651$; , pale green cathedral bottle, $41 \mathrm{BX} 649$; d, aqua ink bottle, $41 \mathrm{BX} 650$; e, blue pressed glass, $41 \mathrm{BX} 651$.

The handle of a silver teaspoon (Fig. 14,a) came from Level 1 in $41 \mathrm{BX} 649$. The recovery of several sherds of porcelain and transferware and banded slipwares from the same level suggests an early 19th-century household of moderate means and some social standing was somewhere in the immediate vicinity.

\section{Animal Bone}

Faunal material from controlled excavations at sites $41 \mathrm{BX} 649$ and $41 \mathrm{BX} 651$ was examined by W. L. McClure, who submitted the following remarks and identifications (see Table 4). There is no significant difference in the faunal material between sites and between the levels in each site.

The bone material from both sites is mostly beef with lesser amounts of fish, chicken, deer, cat, dove, and goat. Site 41 BX 649 also included pig and bluejay, while site 41 BX 651 included Norway rat, cottontail rabbit, and jackrabbit. House cats were kept, and they probably accounted for the rat and perhaps for some of the small birds.

Beef cattle were the dominant food source represented. Cattle may have been slaughtered on the site, and were probably cut into individual portions on the premises. Saws were used and some sort of hacking tool. 


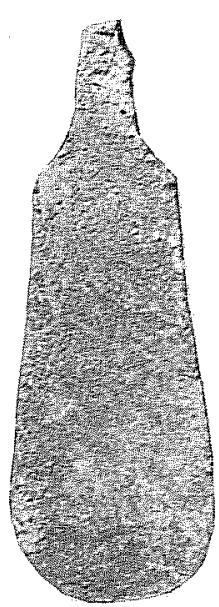

a

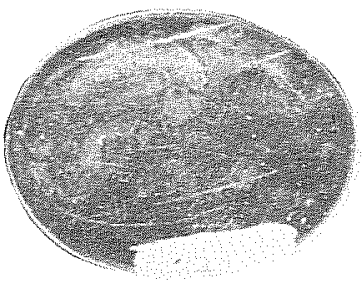

e

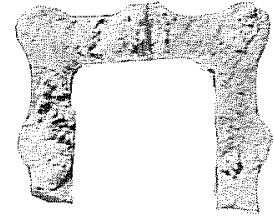

b

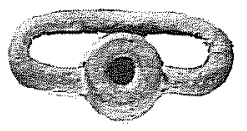

f

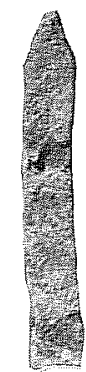

C

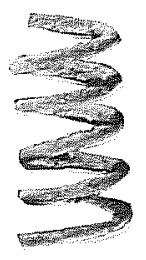

g

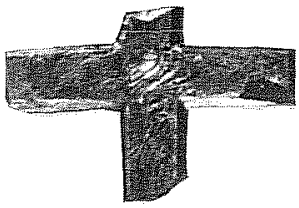

d

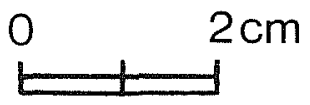

Figure 14. Miscellaneous Artifacts. a, spoon handle, 41 BX 649; b, buckle fragment, 41 BX 649; c, buckle tongue, $41 \mathrm{BX} 649$; d, glass crucifix, $41 \mathrm{BX} 649$; e, eyeglass piece, $41 \mathrm{BX} 650$; f, clock winding stem, $41 \mathrm{BX} 651$; g, spring, $41 \mathrm{BX} 651$.

Pigs, deer, and goats were probably also butchered on the premises. Some hunting and fishing activities were probably of minor importance as food resources.

Some but not all of the bones were exposed to heat after food preparation. Apparently household trash was dumped and burned near the recovery locations. The fragmentary condition of many of the bones suggests that the material may have been subjected to foot traffic or some other impact after primary disposal.

Material from east of the chimney at $41 \mathrm{BX} 651$ included a carbonized stone of the fruit of the Chinaberry (Melia azedarach). This may be documentation of an early (late 18th century) introduction of this shade tree into Bexar County.

Shell

The shell fragments were predominantly river mussel, and were too small for a more detailed identification. One small oyster shell fragment from $41 \mathrm{BX} 651$ and a cowrie shell and pieces of shell from a small unidentified marine gastropod from 41 BX 649 were the only marine shells present. This is, to our knowledge, the first cowrie shell to be recovered from an archaeological site in San Antonio. How it got there is open to speculation. 


\begin{tabular}{|c|c|c|c|}
\hline Provenience & $\begin{array}{l}\text { al Weight (g) } \\
\text { Per Unit }\end{array}$ & Type & Description \\
\hline \multicolumn{4}{|l|}{$41 \mathrm{BX} 649$} \\
\hline N105 W105, L.1 & 752.61 & $\begin{array}{l}\text { Unidentified fish } \\
\text { Unidentified small } \\
\text { mammal } \\
\text { Unidentified medium } \\
\text { mammal } \\
\text { Unidentified }\end{array}$ & $\begin{array}{l}\text { Radius, femur, tibiotarsus fragment, right tarsometatarsus (distal half) } \\
\text { Round steak from tibia (sawed), thoracic vertebra fragment, } 2 \text { sirloin } \\
\text { steaks (sawed @ } 3 / 8 \text { inch), lumbar vertebra steak (sawed @ } 1 / 2 \text { inch), } 4 \\
\text { ribs ( } 3 \text { hacked, } 1 \text { sawed, } 1 \text { dorsal end), ulna fragment (rat gnawed), right } \\
\text { ulna (olecranon, sawed across @ } 2 \text { inches), malleolus right lunar, } 2 \text { right } \\
\text { calcaneous (1 fragment, hacked), phalanx } 1 \text {, phalanx \#2 (hacked as if to } \\
\text { remove phalanx } 3 \text { ) } \\
1 \text { vertebra } \\
15 \text { fragments } \\
2 \text { ribs (dorsal ends), vertebra fragment } \\
145 \text { fragments (most are cow size) }\end{array}$ \\
\hline N105 W105, L.2 & 22.76 & $\begin{array}{l}\text { Chicken } \\
\text { Goat }\end{array}$ & $\begin{array}{l}\text { Tarsometatarsus (male) } \\
\text { Right mandible misection with } 3 \text { teeth }\end{array}$ \\
\hline N105 W105, L.3 & & $\begin{array}{l}\text { Cow } \\
\text { Unidentified fish } \\
\text { Unidentified }\end{array}$ & $\begin{array}{l}\text { Tarsal } \\
1 \text { fragment } \\
53 \text { fragments ( } 20 \text { burned) }\end{array}$ \\
\hline N105 W105 Trench & 16.55 & Unidentified & 6 fragments (burned) \\
\hline N110 W100, L.2 & 343.59 & $\begin{array}{l}\text { Chicken } \\
\text { Cow } \\
\text { Gar } \\
\text { Unidentified bird } \\
\text { Unidentified fish } \\
\text { Unidentified } \\
\text { White-tailed deer }\end{array}$ & $\begin{array}{l}\text { Carpometacarpus; phalanx } \text { 清 } 2 \text { of digit } \# 2 \text { (wing), phalanx (foot) } \\
8 \text { ribs (midsection, hacked), thoracic vertebra ( } 2 \text { fragments), } 2 \text { long bone } \\
\text { fragments } \\
\text { Scale fragment } \\
2 \text { fragments } \\
5 \text { fragments } \\
100 \text { fragments ( } 30 \text { burned, most cow size, } 1 \text { caudal vertebra) } \\
\text { Antler fragment }\end{array}$ \\
\hline N100 W100, L.3 & 305.03 & $\begin{array}{l}\text { Cow } \\
\text { Goat } \\
\text { Unidentified bird } \\
\text { Unidentified fish } \\
\text { Unidentified } \\
\text { White-tailed deer }\end{array}$ & $\begin{array}{l}2 \text { ribs (dorsal ends without heads, hacked @ } 31 / 2 \text { and } 9 \text { inches), } 2 \text { tarsals } \\
\text { Right centroquartal } \\
2 \text { fragments } \\
4 \text { fragments } \\
100 \text { fragments ( } 30 \text { burned, most cow size) } \\
\text { Skull fragment with part of antler, phalanx } 1\end{array}$ \\
\hline N105 W100, L.1 & 309.62 & $\begin{array}{l}\text { Mourning dove } \\
\text { Pig } \\
\text { Unidentified fish } \\
\text { Unidentified medium } \\
\text { mammal } \\
\text { Unidentified }\end{array}$ & $\begin{array}{l}\text { Digit of phalanx \#1 (wing), sternum fragment, cervical vertebra, radius } \\
\text { Right scapula (half of fossa, split by hack, hacked from blade), } 4 \text { ribs (1 } \\
\text { dorsal end, } 3 \text { midsection; } 1 \text { sawed, others hacked), scapula steak (sawed @ } \\
3 / 4 \text { inch), long bone fragment (sawed) } \\
\text { Tarsometatarsus (proximal half) } \\
\text { Canine tooth, } 3 \text { tooth fragments } \\
\text { Scale fragment, dorsal spine, } 3 \text { fragments } \\
\text { Innominate steak (sawed @ } 9 / 16 \text { inch), } 2 \text { vertebrae halves, vertebra } \\
\text { fragment, condyle of metapodial, phalanx } \# 1 \text {, phalanx } \# 2 \\
100 \text { fragments (most are cow size) }\end{array}$ \\
\hline $\begin{array}{l}\text { N105 W100 Posthole } \\
41 \mathrm{BX} 651\end{array}$ & 1.89 & Unidentified & 2 fragments \\
\hline West of Chimney & 759.78 & $\begin{array}{l}\text { Chicken } \\
\text { Unidentified medium } \\
\text { mammal } \\
\text { Chicken }\end{array}$ & $\begin{array}{l}\text { Radius } \\
\text { Thoracic vertebra (fragment of neural spine) } \\
\text { Left humerus (distal half) }\end{array}$ \\
\hline
\end{tabular}




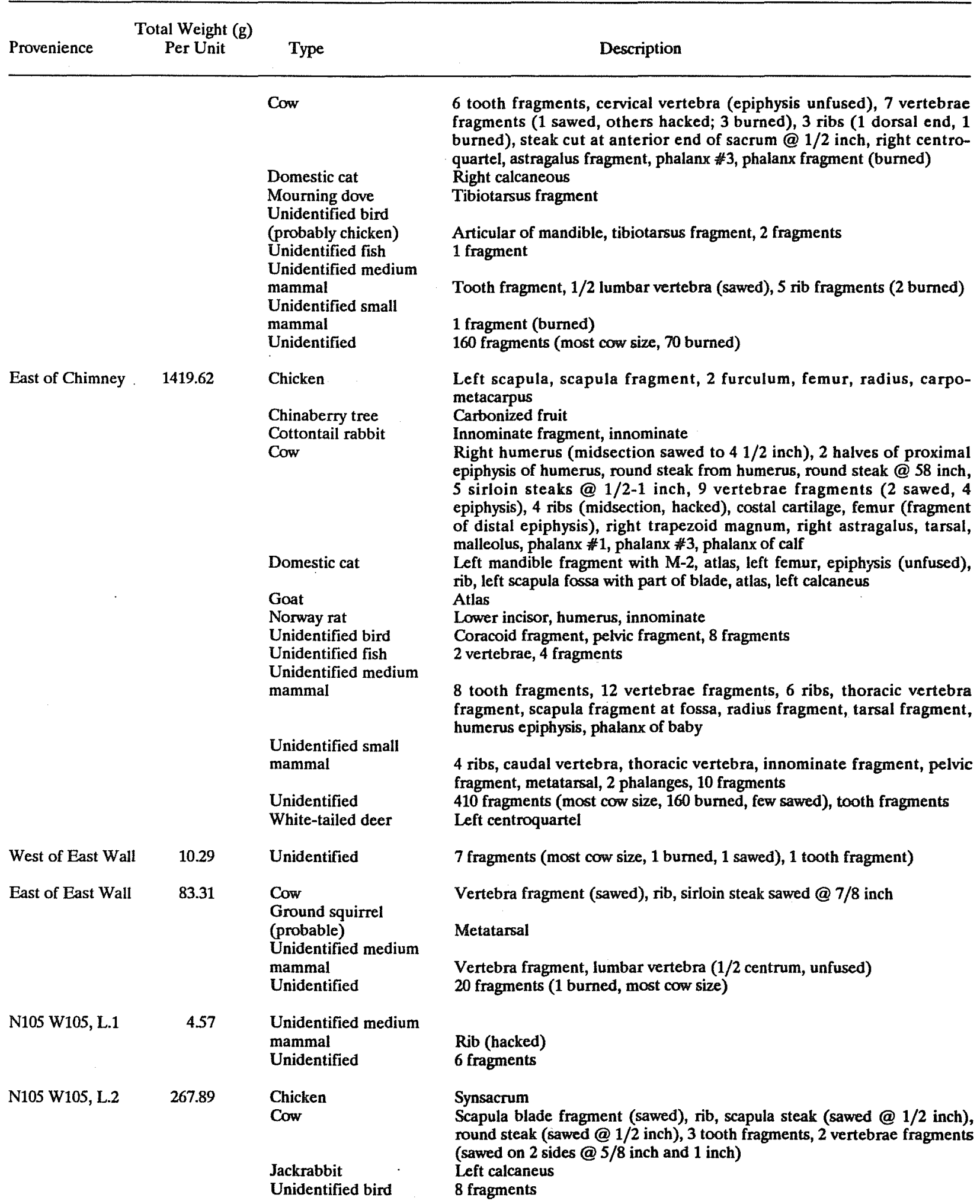


TABLE 4. (continued)

\begin{tabular}{|c|c|c|c|}
\hline Provenience & $\begin{array}{l}\text { Total Weight (g) } \\
\text { Per Unit }\end{array}$ & Type & Description \\
\hline & & $\begin{array}{l}\text { Unidentified medium } \\
\text { mammal } \\
\text { Unidentified } \\
\text { White-tailed deer }\end{array}$ & $\begin{array}{l}\text { Rib, phalanx, fragment } \\
100 \text { fragments (most cow size, } 14 \text { burned, } 5 \text { sawed) } \\
\text { Right humerus (without ends) }\end{array}$ \\
\hline N105 W105, L.3 & 36.43 & Unidentified & 52 fragments (most cow size, 1 rib sawed, 7 burned) \\
\hline N100 W125, L.1 & 25.49 & $\begin{array}{l}\text { Cow } \\
\text { Unidentified }\end{array}$ & $\begin{array}{l}5 \text { tooth fragments } \\
37 \text { fragments ( } 10 \text { burned, most cow size) }\end{array}$ \\
\hline N100 W125, L.2 & 4.57 & Unidentified & $\begin{array}{l}50 \text { fragments (most cow size, } 1 \text { sawed innominate @ } 3 / 4 \text { inch, } 10 \text { burned), } \\
2 \text { tooth fragments }\end{array}$ \\
\hline
\end{tabular}

\section{CLOTHING/PERSONAL/ACTIVITY ITEMS}

Articles placed in the Clothing/Personal/Activity Items category can tell us something personal about the people present on the sites, their clothing, their habits, and their interests.

The assortment of buttons recovered is not out of line with those customarily seen from comparative domestic sites. The interesting concentration of buttons in Level 1 in one spot in the back yard of both 41 BX 649 and $41 \mathrm{BX} 651$ might represent clothes washing activities taking place there (the largest concentration of buttons the CAR archaeologists have ever recovered came from the pit where the water from a commercial laundry was drained).

A delicate buckle (Fig. 14,b) from the 41 BX 649 back yard, Level 2, could be for a woman's dress, or a man's cravat or shoe (DiPeso 1953:Fig. 24). A crudely made brass or copper buckle tongue (Fig. 14,c) from Level 3 at the same site could be from a harness buckle or a man's belt (see similar one in Simmons and Turley 1980:Plate 24). A fine brass chain, a glass crucifix (Fig. 14,d), and a piece of metal filigree from 41 BX 649, Levels 1 and 2, probably represent pieces of jewelry. A faceted blue glass bead and a plain white bead from Level 2 add to the inventory from that site. An oval piece of flat glass (Fig. 14,e) found near the front steps at 41 BX 650 appears to have come from a pair of eyeglasses. Two small silvered glass fragments from a hand mirror complement the feminine articles. Two six-pointed brass stars mounted on thin rusted metal may be from some sort of military insignia.

\section{MISCELLANEOUS ITEMS}

Fragments and numerous teeth came from a dark brown, molded composition comb from Level 1 at $41 \mathrm{BX} 649$. Three brass straight pins came from $41 \mathrm{BX} 651$. Two fragments of white clay pipe stems and a small piece from the bowl of a brown molded clay pipe represent masculine occupants at 41 BX 649 . Also from Level 1 at the same site came three U.S. coins: an 1851 dime, an 1865 nickel, and an 1880 penny. The brass winding stem from a small clock (Fig. 14,f) came from the upper zone in the back yard of 41 BX 651 . A small spring (Fig. 14,g) came from the earlier deposits east of the chimney base at the same site.

The only evidence of the presence of children consists of marbles found on all three sites. Three clay marbles (Fig. 15,a-c) from Level 1 at 41 BX 649 and one from the upper zone of the 41 BX 651 back yard are unglazed. A marble (Fig. 15,d) found near the front steps at 41 BX 650 has a dark brown Bennington glaze (Block 1979:152). Another from the same area is a more modern glass marble such as can still be purchased today.

Fragments of slate were recovered from all three sites. While some of these may represent slates used for writing, most are too thick and irregular to be so categorized and are probably roofing slate. There were, 


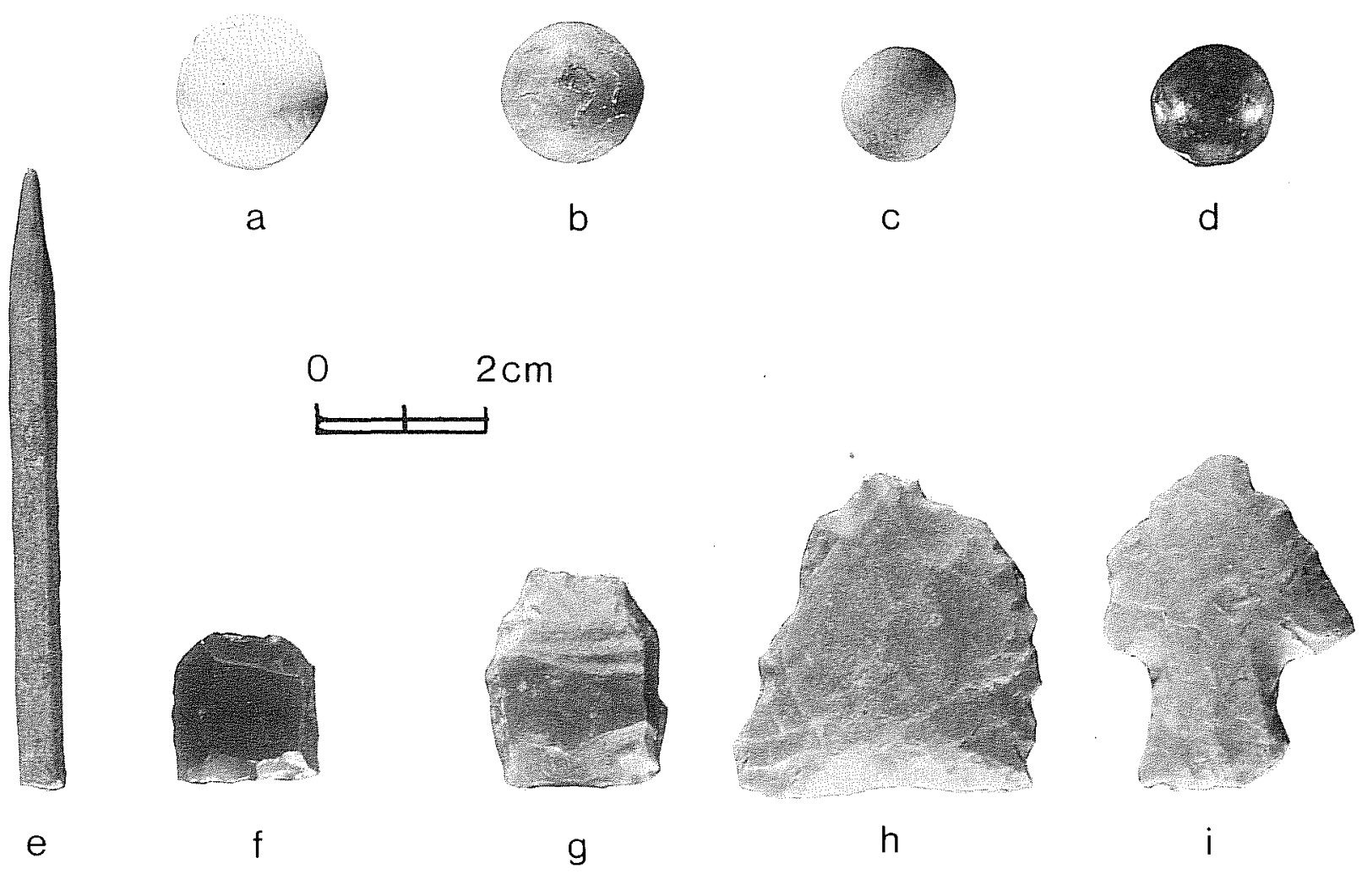

Figure 15. Miscellaneous Artifacts. a-c, clay marbles, 41 BX 649; d, Bennington marble, 41 BX 650; e, slate pencil, 41 BX 649; f, pistol flint, 41 BX 651; g, gunflint, 41 BX 651; h, chert biface, 41 BX 649; i, chert biface, $41 \mathrm{BX} 651$.

however, three slate pencil fragments, two from Levels 1 and 3 at 41 BX 649 (Fig. 15,e) and one from Level 3 at 41 BX 651 behind the house. Pencil leads were also found at both sites in the upper levels. These writing materials could, of course, have been used by adults as well as children.

\section{WORKSHOP ITEMS}

Surprisingly few artifacts were found that relate to back yard workshop activity. A few unidentifiable rusted metal objects that appear to represent such activities as wood and metal working came from $41 \mathrm{BX} 649$ and 41 BX 651. Fragments of wire were found when cleaning the foundation at 41 BX 650 .

\section{ARMS}

Two gunflints were recovered from the back yard at 41 BX 651, one at Level 2 and one at Level 3. The one from Level 2 is an imported pistol flint (Fig. 15,f) made of dark gray brown flint. The other (Fig. 15,g) is more crudely made, possibly large enough for a musket, made of Edwards chert, and has seen much more use than the former. A copper percussion cap came from $41 \mathrm{BX} 649$, Level 1 . This is a small, straight-sided cap rather than the "top hat" variety found on military sites, and probably dates from the mid-19th century (Tordoff 1979:43). A brass ferrule also found in Level 1 at 41 BX 649, may be part of a piece of military equipment. 


\title{
CONSTRUCTION ITEMS
}

Fragments of window glass were found throughout the area under investigation. They range in thickness from $1.0 \mathrm{~mm}$ to $3.0 \mathrm{~mm}$ with the majority from $2.0 \mathrm{~mm}$ to $2.3 \mathrm{~mm}$. It has been established by a number of researchers that the thickness of window pane glass increased through time during the 19th century (Orser 1983:Table 5-3; Weinstein et al. 1988:5-16). Considering the amount of remodeling and demolition that took place on the three sites, and the relatively small percentage of each site that was sampled, there is no particular point in attempting a detailed analysis. The glass fragments from the area east of the chimney at $41 \mathrm{BX} 649$ contained the thinnest fragments $(1.0 \mathrm{~mm}$ to $2.0 \mathrm{~mm})$, which would agree with the early 19 th-century date of the majority of the other artifacts found there.

Nails recovered also represent various periods of construction and remodeling. Both cut nails and the later wire nails introduced into Texas in the $1880 \mathrm{~s}$ are included. No 18th-century hand-forged nails were identified.

A lock plate and a furniture-sized pin hinge were found while cleaning at 41 BX 650 . Various other hardware fragments and screws were found elsewhere during the project.

A few small fragments of brick found in the first level at $41 \mathrm{BX} 649$ probably relate to the construction phase of $41 \mathrm{BX} 650$. Red, yellow, and salmon-colored brick fragments recovered at $41 \mathrm{BX} 651$ relate to the later brick addition on the front of the building, which appears to have been done with salvaged brick since they were of irregular sizes and colors. A number of sample bricks were retained from the wall cleaning at $41 \mathrm{BX} 650$ for comparison with bricks from other San Antonio sites in the CAR laboratory. Marked bricks from $41 \mathrm{BX} 650$ (many were not marked but all were the same color and general size) were as follows:

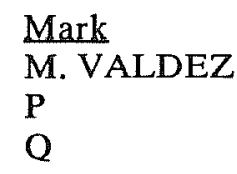

\author{
Measurement \\ $8-1 / 2 \times 4 \times 2-1 / 2$ inches \\ $8 \times 4 \times 2-1 / 4$ inches \\ Incomplete
}

All were a yellow tan color. Similar Laredo bricks were recovered from excavations at the Hot Wells Hotel south of San Antonio (Fox and Highley 1985) which was built in 1910, and from numerous other sites containing late 19th-century buildings in downtown San Antonio.

Most of the plaster recovered from controlled excavations at 41 BX 649 and 41 BX 651 was relatively hard, of fine sand and lime, with a 0.5 -mm-thick coating of pure white lime plaster bearing traces of whitewash. A few fragments from Level 1 at 41 BX 649 also bore a thin pink wash. Fragments of cement plaster were also outside of the foundation at $41 \mathrm{BX} 651$, probably added during the remodeling of the structure in the early 20 th century.

\section{CHERT}

Numerous chert fragments were found in the deposits, which is common everywhere in downtown San Antonio. Of these, two are obvious artifacts, showing signs of purposeful alteration. A bifacial tool (Fig. 15,h) from Level 2 at 41 BX 649 shows numerous signs of battering and possible use as a cutting tool. A resharpened, stemmed prehistoric projectile point (Fig. 15,i) from Level 1 in the back yard at 41 BX 651 has seen a great deal of use as some sort of tool.

\section{SUMMARY AND RECOMMENDATIONS}

Archaeological and historical investigations of Lot A24, NCB 132 have resulted in the documentation of

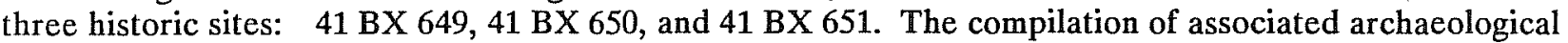
data from subsurface excavations has helped to interpret and isolate sequences of land use probably dating from the late 1700s through the mid 1900s. The lot area was open, cultivable land on the north end of San 
Antonio in the 1700s before the extension of Flores Street (Fig. 2). Later use of the lot included the construction of residential structures at $41 \mathrm{BX} 649,41 \mathrm{BX} 650$, and $41 \mathrm{BX} 651$, and later utilization of $41 \mathrm{BX} 651$ for commercial purposes. The later remodeling of the $41 \mathrm{BX} 651$ structure for commercial purposes sometime after 1927 is indicated by at least three sequences of remodeling and concomitant leveling of areas to the west for commercially related activities. The following brief chronological summary is used to elucidate the findings at Lot A24.

Early historic land use entailed the utilization of the rich alluvial soils that underlie the lot. Though not substantiated by archaeological investigations at the lot, it is probable that the nearby San Pedro acequia was being used to irrigate the open land (cf. Valdez and Eaton 1979:1-3). Historic ceramics concentrated in the upper 12 feet of natural clayey alluvium indicate an exposed surface dating from the late 1800s. During that period, alluvium from flooding combined with plowing buried and mixed the cultural deposits. The high frequency of ceramics found nearer Flores Street is contrasted by the low frequency from test units and foundation clearing west of $41 \mathrm{BX} 650$ and $41 \mathrm{BX} 651$. This indicates a combination of redeposition from street construction and probably a high incidence of use of that area for dumping trash. The high frequencies of bone in the same strata from animals being butchered on the premises would also be indicative of dumping from nearby residences onto the clay surface.

Primary construction appears to have taken place about 1850 with the structure on the corner of North Flores and Salinas Streets. An early architectural style is evidenced by a jacal wall trench found at $41 \mathrm{BX} 649$ which probably represents the remains of a back yard structure or fence. The caliche-packed trench was dug into the alluvial surface to support wall posts. The structures on the site were probably demolished in 1898 as preliminary leveling for the construction of the house at $41 \mathrm{BX} 650$.

About 1868, later residential construction and a different architectural style are evidenced at 41 BX 651 . Dressed limestone and mortar footings were sunk three feet into the clay zone. Walls were constructed of dressed limestone and mortar and faced with a cement plaster. At that time, the structure was a single story adobe with what appears to be a detached kitchen (Koch 1873). Sometime between 1882 and 1898, a west wing was added onto the northwest corner.

In 1898, the Thaddeus Smith family, occupants of the adobe house at 41 BX 651 , constructed the multistoried Romanesque revival-style house whose foundations were exposed at $41 \mathrm{BX} 651$. The footings consisted of courses of brick set into the alluvial clay. The exterior walls of the house were brick faced with limestone, giving the appearance of stone construction (Fig. 7). This marked the last residential construction documented during investigations.

During the occupation of the house at $41 \mathrm{BX} 650$, the house at $41 \mathrm{BX} 651$ was still being used as a residence. This changed about 1927 when the property began to be used for commercial purposes. The original building was refaced and somewhat enlarged. To do this, the front wall (east wall) was bulldozed into the area between the limestone foundation to form a portion of the fill in support of a concrete pad that acted as a floor for the enlarged interior. Later commercial uses included a laundry, restaurant, and sign painting shop. Several strata of fill in the western area of $41 \mathrm{BX} 651$ demonstrate that the surface was being leveled for commercial use. Evidence includes bluish staining of one of the surfaces probably associated with the sign shop; remnants of cedar posts would have supported a platform probably used as a loading dock. Trash found in the upper zones near the concrete pad on the west was indicative of restaurant discards from the later occupations. Later commercial use is also documented at $41 \mathrm{BX} 650$. After the death of Thaddeus Smith in 1936, the structure became rental property until 1957 when it became the headquarters for KEXX radio. In 1958, the lot was purchased by the City of San Antonio. The remaining structures at 41 BX 650 and 41 BX 651 were demolished and their foundations covered with caliche fill and asphalt for a parking lot.

Within the relatively small confines of the project area, evidence of four different occupations that relate to four different stages in the development of the city of San Antonio was found. The following outlines the dates for these occupations at each site investigated.

1. A mid-18th-century occupation at $41 \mathrm{BX} 651$ directly related to the early settlement of the town of San Fernando de Bejar (Fig. 2). The evidence is entirely artifactual and consists of what appears to have been 
a trash deposit in the soil into which the footings of a later house were dug. The trash probably originated from a house located at what was then the end of Flores Street, just outside the present project area.

2. A house site at $41 \mathrm{BX} 649$ relates to the early 19 th-century spread of the settlement toward the north and infilling of new homes among the earlier ones. Evidence for this site consists of a row of postholes which could be from a fence or a jacal dug into trash deposits in the back yard of a house that faced onto Flores Street (Fig. 3).

3. A mid-19th-century house site at $41 \mathrm{BX} 651$ was occupied by various families, including that of Thaddeus Smith until 1898, then used for commercial purposes until it was razed in 1958. The evidence consists of footings and foundations of the house as it was originally built and of later additions as well as artifacts left by the various occupants.

4. A turn-of-the-century Victorian house at $41 \mathrm{BX} 650$ was built for the Smith family in 1898 . Here the evidence recovered consists primarily of the footprint of the house and a few artifacts found around it. The design of the house is directly related to that of numerous houses of wealthy and influential citizens of San Antonio in the late 19th century (see Hagner 1940 and Burkholder 1973).

The archaeological and historical investigations of sites $41 \mathrm{BX} 649,41 \mathrm{BX} 650$, and $41 \mathrm{BX} 651$ have mitigated impact from highway construction. Further work at these sites is considered unnecessary. Areas along the southern edge of the lot bordering on Salinas Street (see Fig. 2) have been identified as possible locations for buried structural remnants that may date to early 19th-century and possible late 18th-century occupations. Since the area was not within the proposed highway boundaries, no work was attempted there. It is recommended that the area be protected by National Register and State Archeological Landmark status. If further work is planned in the area, additional subsurface documentation will be required along the north side of Salinas Street.

\section{REFERENCES CITED}

Barber, E. A.

1904 Marks of American Potters. Patterson and White Company, Philadelphia.

Barnes, M. and R. V. May

1972 Mexican Majolica in Northern New Spain. Pacific Coast Archaeological Society Occasional Paper 2.

Bexar County, Texas

Deed Records $(D R)$

Office of the County Clerk, Bexar County Courthouse, San Antonio, Texas.

Wills and Probate Records

Originals and microfilm located in the Office of the County Clerk, Bexar County Courthouse, San Antonio, Texas.

Block, S.

1979 Marbles, Playing for Run and for Keeps. In The Encyclopedia of Collectibles, Lalique to Marbles. Time-Life Books, Alexandria, Virginia. 
Bureau of Economic Geology

1985 Geologic Atlas of Texas. San Antonio Sheet, Scale 1:250,000. The University of Texas at Austin.

Burkholder, M. V.

1973 The King William Area, A History and Guide to the Houses. The King William Association, San Antonio.

Chabot, F. C.

1937 With the Makers of San Antonio. Privately published, San Antonio.

City Directories

1883- . Located at San Antonio Public Library, San Antonio, Texas.

1958

Cox, I. W.

1989 Property Ownership and Monitoring for the Martin and Bowie Streets Modification (East), San Antonio, Bexar County, Texas. Center for Archaeological Research, The University of Texas at San Antonio, Archaeological Survey Report 185. In preparation.

Davis, E. M, and J. E. Corbin

1967 Archeological Investigations at Washington-on-the-Brazos State Park in 1966. State Building Commission Archeological Program Report 5.

Deagan, $\mathrm{K}$.

1987 Artifacts of the Spanish Colonies of Florida and the Caribbean, 1500-1800. Volume 1: Ceramics, Glassware, and Beads. Smithsonian Institution Press, Washington D.C.

DiPeso, C. C.

1953 The Sobaipuri Indians of the Upper San Pedro River Valley, Southeastern Arizona. The Amerind Foundation Publications 6. Dragoon, Arizona.

Ellis, W. B.

1986 Preliminary Archaeological Assessment of the Northeast Parking Lot Area (Phase III), Site of the New Bexar County Justice Center, San Antonio, Texas. Draft report on file at the Center for Archaeological Research, The University of Texas at San Antonio.

Fox, A. A.

1974 Lead Glazed Wares. In Mission Rosario, Archeological Investigations in 1973, by Kathleen Gilmore. Texas Parks and Wildlife Department, Historic Sites and Restoration Branch, Archeological Report 14, Part 1.

1977 The Archaeology and History of the Spanish Governor's Palace Park. Center for Archaeological Research, The University of Texas at San Antonio, Archaeological Survey Report 31. 
Fox, A. A. (continued)

1978 Preliminary Archaeological Assessment of South Parking Lot Area (Phase I), Site of Courthouse Annex, San Antonio, Texas. Letter report to Bexar County Commissioners Court.

1982 Assessment of Garza House, 214 Salinas Street, San Antonio. Report submitted to Bernard Lifschutz, San Antonio.

1986 Ceramics. In La Villita Earthworks (41 BX 677): San Antonio, Texas. A Preliminary Report of Investigations of Mexican Siege Works at the Battle of the Alamo, assembled by J. H. Labadie:107-127. Center for Archaeological Research, The University of Texas at San Antonio, Archaeological Survey Report 159.

Fox, A. A., I. W. Cox, L. Highley, and D. Hafernik

1989 Archaeological and Historical Investigations at the Site of the New Bexar County Justice Center in Downtown San Antonio, Texas. Center for Archaeological Research, The University of Texas at San Antonio, Archaeological Survey Report 184.

Fox, A. A. and C. L. Highley

1985 History and Archaeology of the Hot Wells Hotel Site, 41 BX 237. Center for Archaeological Research, The University of Texas at San Antonio, Archaeological Survey Report 152.

Fox, D. E., D. Scurlock, and J. W. Clark, Jr.

1977 Archeological Excavations at San Fernando Cathedral, San Antonio, Texas: A Preliminary Report. Office of the State Archeologist Special Report 22.

Freisleben, G.

n.d. San Antonio de Bexar and its Ancient Wards. Barker History Center, The University of Texas at Austin.

Frkuska, A. J., Jr.

1981 Archaeological Investigations at the San Pedro Acequia, San Antonio, Texas. Center for Archaeological Research, The University of Texas at San Antonio, Archaeological Survey Report 103.

Gerald, R. E.

1968 Spanish Presidios of the Late Eighteenth Century in Northern New Spain. Museum of New Mexico Research Records 7, Museum of New Mexico Press, Santa Fe.

Gilmore, K.

1974 Mission Rosario, Archeological Investigations in 1973. Texas Parks \& Wildlife Department, Historic Sites and Restoration Branch, Archeological Report 14, Part 1.

Godden, G. A.

1975 British Pottery, An Illustrated Guide. Clarkson N. Potter, Inc., New York. 
Goggin, J. M.

1968 Spanish Majolica in the New World, Types of the Sixteenth to Eighteenth Centuries. Department of Anthropology, Yale University Publications in Anthropology 72. New Haven, Conn.

Hagner, L. M.

1940 Alluring San Antonio, Through the Eyes of an Artist. The Naylor Company, San Antonio.

Ivey, J. E.

1982 Menger Soap Works. Center for Archaeological Research, The University of Texas at San Antonio, Manuscript Series 12.

Ivey, J. E. and A. A. Fox

1981 Archaeological Survey and Testing at Rancho de las Cabras, Wilson County, Texas. Center for Archaeological Research, The University of Texas at San Antonio, Archaeological Survey Report 104.

Katz, P. R.

1978 Archaeological and Historical Investigations in the Arciniega Street Area, Downtown San Antonio, Texas. Center for Archaeological Research, The University of Texas at San Antonio, Archaeological Survey Report 61.

Kendall, D. S. and C. Perry

1974 Gentilz, Artist of the Old Southwest. University of Texas Press, Austin.

Koch, A.

1873 Bird's Eye View of the City of San Antonio, Bexar County, Texas, 1873. Reproduced from the collection of the San Antonio Museum Association. Published by R. H. Holland.

Labadie, J. H., assembler

1986 La Villita Earthworks (41 BX 677): San Antonio, Texas. A Preliminary Report of Investigations of Mexican Siege Works at the Battle of the Alamo. Center for Archaeological Research, The University of Texas at San Antonio, Archaeological Survey Report 159.

Lister, F. C. and R. H. Lister

1974 Maiolica in Colonial Spanish America. Historical Archaeology 8:17-52.

Munsey, C.

1970 The Illustrated Guide to Collecting Bottles. Hawthorn Books, Inc., New York.

Orser, C. E., Jr.

1983 A Mean Flat Glass Dating Method for the Southeastern United States. Manuscript on file, Department of Geography and Anthropology, Louisiana State University, Baton Rouge. 
Sanborn Map and Publishing Company, Ltd.

1896, Map of San Antonio, Texas. New York.

1904

Seifert, D. J.

1977 Archaeological Majolicas of the Rural Teotihuacan Valley, Mexico. Ph.D. dissertation, University of Iowa, Iowa City.

Simmons, M. and F. Turley

1980 Southwestern Colonial Ironwork, The Spanish Blacksmithing Tradition from Texas to California. Museum of New Mexico Press, Santa Fe.

Taylor, F. B., R. B. Hailey, and D. L. Richmond

1966 Soil Survey of Bexar County, Texas. United States Department of Agriculture, Soil Conservation Service, in cooperation with the Texas Agricultural Experiment Station, Series 1962(12).

Tordoff, J. P.

1979 Some Observations on the Quantitative Relationship Between Stanley South's Artifact Patterns and "Primary DeFacto" Refuse. Historical Archaeology 13:38-47.

Toulouse, J. H.

1971 Bottle Makers and Their Marks. Thomas Nelson, Inc., New York.

United States Department of the Interior, Office of the Census (USDI-OC)

1880 The Tenth Population Census, 1880. Bexar County, Texas.

Valdez, F., Jr., and J. D. Eaton

1979 Preliminary Archaeological Investigations of Part of the San Pedro Acequia, San Antonio, Texas. Center for Archaeological Research, The University of Texas at San Antonio, Archaeological Survey Report 85.

Urrutia, J. de

1767 San Antonio, Texas in 1767. Department of Manuscripts, The British Library, London.

Weinstein, R. A., T. H. Hahn III, M. S. Henson, D. B. Kelley, and J. P. Whelan, Jr.

1988 Archaeological Testing and Mitigation at Cedar Hill Park, Chambers County, Texas. Coastal Environments, Inc., Baton Rouge. Manuscript submitted to U.S. Army Corps of Engineers, Galveston District. 



